INSIGHTS INTO REGIONAL DEVELOPMENT

ISSN 2669-0195 (online) http://jssidoi.org/IRD/

2021 Volume 3 Number 3 (September)

http://doi.org/10.9770/IRD.2021.3.3(5)

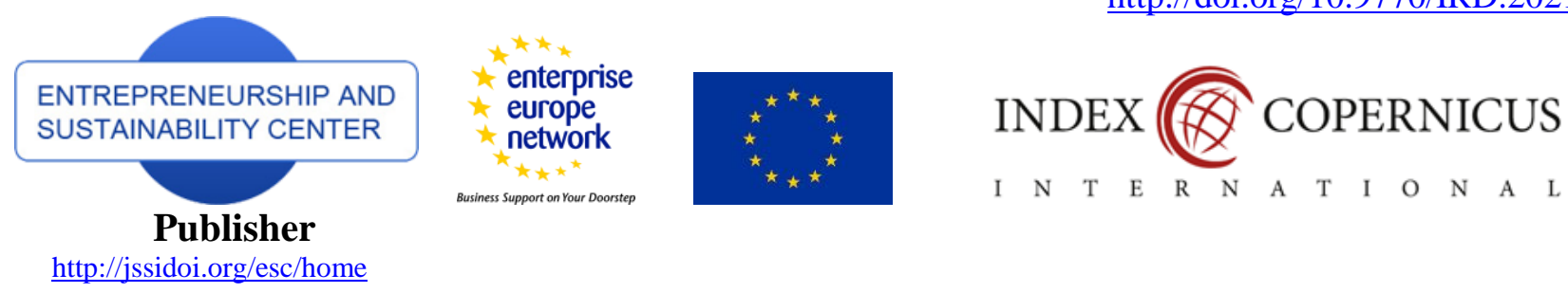

\title{
EFFECTIVENESS AND EFFICIENCY CRITERIA FOR STRATEGIC APPLICATION OF MECHATRONICS IN BUSINESS PROCESSES
}

\author{
Mindaugas Laužikas ${ }^{1}$, Aistė Miliūtė ${ }^{2}$, Viltė Morozovaitė ${ }^{3}$, Danielius Karpičius ${ }^{4}$ \\ ${ }^{1}$ Global Innovation Learning Ecosystem (GILE) Experts, Corradino Industrial Estate, Paola, Malta \\ ${ }^{2}$ UAB “AKVAVITA", Neravu 100, Vieciunai, Lithuania \\ 1,2,3,4 Vilnius University Business School, Saulètekio Av. 22, LT-10225 Vilnius, Lithuania \\ E-mails: ${ }^{1}$ mindaugas.lauzikas@gmail.com; ${ }^{2}$ aiste_miliute@yahoo.com; ${ }^{3}$ vilte.morozovaite@gmail.com; \\ ${ }^{4}$ danielius.karpicius@gmail.com
}

Received 15 January 2021; accepted 25 July 2021; published 30 September 2021

\begin{abstract}
The present paper is centred on the effects of mechatronics in both high-tech and technologically less intensive firms. The strategy of innovation implementation in the mechatronics industry is tackled from both the high-tech business development perspective and the mechatronics product application perspective in other industries. Although the scientific and statistics literature with regards to the modern technology's effects is well established, the scarcity of scientific research in the field of the application of mechatronics/robotics in business makes this topic of significant scientific value. The purpose of this paper is to examine the effectiveness and efficiency criteria for the strategic application of mechatronics in businesses, related to both the decision-making process at the top-management level as well as choosing, applying, and monitoring the success of mechatronics among institutional clients. Given that mechatronics' application efficiency depends on a business model and the innovation culture, a focus on two categories of companies in terms of technological intensity could help businesses to choose the right high-tech product and the proper corresponding innovation commercialization model. Moreover, the paper could serve mechatronics firms while implementing the product/service or process innovations that are closer to consumer needs or specific industry challenges. Qualitative semi-structured expert interviews with four IT and four textile managers were conducted, and the conceptual model (which derives from the literature review) was tested. The choice of Lithuania as a target market for the analysed companies is related to the transition of this Baltic economy from the efficiency to the innovation-driven category, where the combination of high and low tech may be able to intensify the innovation process as well as to answer the research question of how to unlock the potential of mechatronics in business processes.
\end{abstract}

Keywords: entrepreneurship; mechatronics; business intelligence; efficiency-driven countries; innovation-driven countries; business processes; effects; high-tech; technological intensity

Reference to this paper should be made as follows: Laužikas, M., Miliūtè, A., Morozovaite, V., Karpičius, D. 2021. Effestiveness and efficiency criteria for strategic application of mechatronics in business processes. Insights into Regional Development, 3(3), 79-105. http://doi.org/10.9770/IRD.2021.3.3(5)

JEL Classifications: $\mathrm{O} 32$ 


\section{INSIGHTS INTO REGIONAL DEVELOPMENT}

ISSN 2669-0195 (online) http://jssidoi.org/jesi/

2021 Volume 3 Number 3 (September)

http://doi.org/10.9770/IRD.2021.3.3(5)

\section{Introduction}

The tradition of using mechatronics technology within various business processes across different departments goes back to the 1950s, but its origins can be found in Ancient Greece (for instance, moving statues - Eisenträger et al. 2018). Important to this topic is the transformation from simple mechanical systems to a more complex and sophisticated technology consisting of various components, such as electronics, mechanics, software, and digital control systems. The mechatronics innovation has helped many companies strengthen their competitive advantage while adapting to changing market conditions and the technological evolution, which over recent decades has become an integral part of business intelligence (driven by profitability, quality, creativity, and efficiency).

Avgoustinov (2007) identifies a number of manufacturing drivers, such as quality, costs, time to market, price, and collaboration: the authors focus on both effectiveness (which is related to the decision-making process and an understanding of the strategic directions in the context of changing competition) and efficiency (business process optimization, execution, and the value-added from various expenditure lines). Many of these drivers are incorporated in the economies that have entered the innovation-driven stage. For example, effectiveness, innovation, and business efficiency are among the main drivers of Lithuanian companies (the Department of Statistics of Lithuania, the Global Innovation Index and Global Economic Forum, 2018). Thus, the application of mechatronics in business processes is gaining momentum among both business professionals and scholars (Hartmann et al., 2002) because it is related to service and product innovation, particularly in fields such as the aircraft and automobile industries. It also has links with a vast spectrum of technology, such as information technology, electronics, and mechanical elements or new intelligent and controllable systems. Moreover, a rich diversity of AI techniques is oriented to more effective and sustainable management while helping companies create the higher social and economic value.

A more contemporary interpretation of the term mechatronics is rather holistic - it is related to the fulfilment of society's needs, providing the opportunity for the enhancement of technological skills and business intelligence competencies or creating an adequate innovation climate for employees to efficiently use electronic machines and smart technologies within the lifelong learning process. As it was discussed by Bishop (2002), while relying on Asimov's (1950) tradition, we have witnessed the evolution of the concept of mechatronics from involving engineering, automated machines, and artificial intelligence to a more holistic notion of mechatronics. Moreover, the image people have of mechatronics being used to make futuristic robots differs from the image they have of it when it's used for science, engineering, and manufacturing, where an embedded solution can be distinguished by its technological sophistication, size, materials, and sensor systems (Arkin, 2000). Notwithstanding that a humanlike robot is still a popular cultural image, mechatronics is involved in the improvement in a great variety of areas, such as integrated bio electro-mechanical systems, quantum physics, nanotechnologies, and business process management (Bishop, 2002).

Although robots can help companies to process big data, many high-tech companies, for instance Kodak, Nokia, and Xerox, struggled to adapt to the new mechatronics era (Aaslaid, 2018), where manufacturing was centred on the trends of replacing people in everyday tasks, for instance, in production lines (Braga, 2001).

Relying on Kikuchi et al.'s (1998, 2008) examples and interpretation of modern technologies as well as Mori's (1969) Yasakawa Internal Trademark Application Memo, Bolton (1995) and Pannaga et al. (2013) continued focusing on connecting a vast spectrum of dimensions, such as electronics, control engineering, and mechanical engineering, while showing how mechatronics is also a part of the complex systems that are based on decisionmaking. Despite the fact that within the later studies, the design of advanced robotics and mechatronics is linked via different types of intelligence, the fusion of 'mecha' (mechanism) and 'tronics' (electronics) is being continuously followed by many scholars (Dorf, 2004), and it is in line with the essence of hybrid technological 


\section{INSIGHTS INTO REGIONAL DEVELOPMENT}

ISSN 2669-0195 (online) http://jssidoi.org/jesi/

2021 Volume 3 Number 3 (September)

http://doi.org/10.9770/IRD.2021.3.3(5)

innovation in the context of the Fourth Industrial Revolution (Frank et al., 2019). The increasing role of technologies (such as information communication, computation technology, and nanotechnology) in business processes leads to next-generation digital solutions for performance optimization and sustainability.

Today, AI-based technologies are efficiently used in many business processes, particularly services such as online banking, anti-money laundering systems, or smartphone personal assistants (Burstein and Holsapple, 2008). Business intelligence becomes a vital catalyst in light of big data management, which helps businesses create and maintain value and competitive advantages over a period of time, while augmented reality manipulations in the physical reality reveal possibilities for product, process, and service improvement, such as when someone shops online.

A striking feature of mechatronics is its diverse applicability along with numerous classifications. Braga (2001) classified mechatronics into a set of focus areas (such as artificial intelligence, business intelligence, and augmented reality) which helped scientists better understand the mechatronics technology and its application specificity. Without these pillars it would be difficult to improve quality, productivity, the decision-making process, data management, operational efficiency, visualization, collaboration, and consumer experience.

Over the last two decades, the elements, areas, and functions of mechatronics-related technology were placed into a clearer structure and more clearly classified. For instance, Bishop (2007) in the handbook Mechatronic Systems, Sensors and Actuators, distinguished five main elements of a mechatronic system: actuators and sensors, signals and conditioning, the digital logic system, software and data acquisition systems, and computers and display devices. To continue, Soudahar (2015) underlined four disciplinary foundations for mechatronics: mechanical engineering, electrical engineering, computer engineering, and computer/information systems. Mechatronics classifications are becoming more complex and detailed, which shows the increasing role of this modern technology and links various technological aspects together. Robotics/mechatronics influence the effectiveness and efficiency of business processes both directly via their application and through the improvement of new technologies, such as artificial intelligence (AI), business intelligence (BI), and augmented reality (AR). From big data handling to increased operational efficiency, the combination of robotics/mechatronics with innovative technologies allows businesses to gain competitive advantages in their complex markets.

A combinations of research methods including a literature review, case studies, comparative analysis, and qualitative expert interviews was chosen to answer the question, "How can we unlock the potential of mechatronics and improve competitive advantages for high-technology and technologically less-advanced companies while facing the pressure to create higher value for stakeholders?" Moreover, the positive experience of the selected firms when they shifted to the innovation-driven stage led to business performance improvement recommendations for both categories of firms.

\section{Literature review}

\subsection{The role of mechatronics in innovation-driven business development}

Mechatronics, being tightly liaised with different types of intelligence, has become an integral part of strategic management and business process optimization systems. According to Eckert et al. (2017), this modern technology is among eight technologies (artificial intelligence, augmented reality, blockchain, drones, the Internet Things (IoT), robots, virtual reality, and 3D printing) that has the most significant impact on business sustainability. It helps businesses to adapt to market trends, is upgradable and customizable, and it possesses the potential to become a product/service or process for the mainstream market while attracting public and private investment. 


\section{INSIGHTS INTO REGIONAL DEVELOPMENT}

ISSN 2669-0195 (online) http://jssidoi.org/jesi/

2021 Volume 3 Number 3 (September)

http://doi.org/10.9770/IRD.2021.3.3(5)

According to PricewaterhouseCoopers (2019), almost three fourths of their interviewed CEOs were concerned about the intensity of technological development, while more than half of the respondents claimed that new technologies would become 'game changers' in their businesses in the upcoming few years. Such future development trends are rather logical because $31 \%$ of businesses have successfully invested in robotics over the past three years, while by 2030, the highest expected returns from artificial intelligence is anticipated in China and North America; moreover, 24\% of businesses have significantly invested in AR in the past three years (PricewaterhouseCoopers, 2019). The role of Essential Eight Technologies to advance digital transformation was also mentioned by Englisch at al. (2019).

Similar 'game changers' were accentuated by Nilson (1980), who described robotics as critical for successful AI implementation. To continue, over the past three years, such terms were used as a fundamental reference by several authors, such as Marinescu et al. (2019), Diaz and Rudolf (2019), and Botea et al. (2019). Ong et al. (2008) added that virtual and augmented reality can help enhance manufacturing process via process innovation. Over the past few years, nearly all the modern technologies drew the attention of a great number of scholars. Treiblmaier and Beck (2019), examined business transformation opportunities through blockchain (how this technology could affect the consumer value proposition). Robotics was also frequently analysed in the context of modern technology impacts; for instance, Wilson (2015) emphasized the profit margin, quality, flexibility, and sustainability aspects, crucial for a technology-driven company.

Taking into account that many world-reknowned companies such as Apple, BMW, and ABB Group use or produce robots and power and automation technologies, the R\&D culture (along with the corresponding input and innovation commercialization processes) are gaining momentum. Bekey et al. (2008) admit that the R\&D department links different dimensions of business strategy (such as marketing/sales, HR, finance, or monitoring) and helps reach efficiency and productivity goals. In parallel with stronger R\&D efforts, the innovation-driven companies in the US and the EU dedicate a greater percentage of their budgets to technological advancement and various R\&D solutions, which contributes to faster internationalization and growth (Iversen et al., 2016), driven by digitalization.

3D printing (with leading companies such as Materialise) is another example of modern technology which is closely related to mechatronics. Thanks to computer simulations and modelling, the combination of software and hardware, and additive manufacturing, this technology is marked by the capability to serve industries such as health care, art and design, aerospace, and consumer goods (Fried Vancraen, 2019, CEO of Materialise). Within their study 'Fabricated: The New World of 3D Printing', Kurman and Lipson (2012) admitted that the option to make things that people need contributed to better living. While tackling the combination of video gaming and virtual reality, a thorough look could be given to Tencent Holdings Ltd. (2019), with revenue of 41 billion euros in 2018, thanks to globally popular games such as 'League of Legends', 'Fortnite', 'Player Unknown's battlegrounds', 'FIFA online'.

In light of emerging digital technology solutions, the capabilities to test a product become more tangible: any product, system, or machine should go through a thorough technical analysis that consists of various engineering aspects, such as regulations, scientific insights, and design. In spite of the scope and the scale of projects (from the longest roads and bridges to engineering the design of various mining systems), companies such as Fluor Corporation (2020) can successfully meet consumer expectations (for instance, precise engineering and design), which is in line with Kececi's (2018) accentuated technical analysis before making any product or system.

Moreover, many next-generation solutions, such as propulsion systems, are used on ships, rockets, satellites, space craft, and various motor vehicles. For instance, one of the leading global companies in rocket propulsion systems is Wickman Spacecraft \& Propulsion (WSPC, 2020). In the context of emerging technology, Raven (1994) also accentuated the importance of automatic control systems in all the fields of engineering. The multiple 


\section{INSIGHTS INTO REGIONAL DEVELOPMENT}

ISSN 2669-0195 (online) http://jssidoi.org/jesi/

2021 Volume 3 Number 3 (September)

http://doi.org/10.9770/IRD.2021.3.3(5)

applicability of control systems (including biological propulsion, robotics, material handling, surgical, aeronautics marine and the defence or space industries) make companies, such as Control Systems Inc. (2019), undeniable influencers among other high-tech firms.

Any technology, from data processing and performance calculations to transport technology (for instance, highspeed trains and aircraft), uses various types of mechatronics; thus, companies such as International Business Machines Corporation (2020) show how to link hardware, software, and hosting and consulting services to research-driven hybrid innovation in various business areas and segments, which creates many new opportunities for car manufacturers (Fournier, 2017).

Modern technology plays a significant role in strategic planning and coordinating and monitoring organizations while making it possible to calculate various performance indicators, helping in quantitative research, generating reports, and/or analysing consumers', employees', and other stakeholders' needs (which is a holistic umbrella concept). For instance, Lee, Joon-Peel and Chang, Myung-Hee (2018) emphasize the role of modern technology tools and systems in data management and innovation diffusion. In 2005, Larry English, one of the most highly respected data researchers of the century, added that business intelligence was divided into two pillars: the quality of information in well-designed data stores, and business-friendly software which provides access to the knowledge and skills of effective analysis.

Thus, business intelligence entails the application of computing technologies to select, filter, and analyse business data, which is used for forecasting and decision-making processes. Moreover, a successful integration of business intelligence into various business procedures calls for the supply of the right technology and an adequate number of analysts. Gorman (2013) describes the nature of BI as a tool assisting to efficiently analyse the past and present, which provides the right people with access to the right data at the right time; therefore, it could be applied in the majority of business departments. For example, within the finance department, business intelligence allows the usage of various resources to be optimized with corresponding expenditures as well as progress to be monitored, while the HR department could use it in monitoring employees' motivation, turnover, productivity, efficiency, creativity, leadership, and many other aspects (Englisch et al. 2019).

Given the increasing role of information technology departments, business intelligence allows the information security of a company to be optimized as well as the underperforming elements of a system to be eliminated. Moreover, using business intelligence in marketing leads to improved consumer value proposition, customer segmentation, social image, revenue growth, and market share, while the R\&D culture supports innovation processes, creative initiatives, and the production of edgy new products and aids in cost cutting via process innovation and leads to lower rates of delays, complaints, or errors. As stated by Hammer and Champy (2006), companies started to optimize the entire business process through the development of information technology and the application of high-tech solutions in practice. The main aim of business process optimization is the harmonization of the related processes and the elimination of the elements that do not add value. All in all, the usage of business intelligence applications can be beneficial in providing decision-makers with critical data (regarding the competition, demand, technology, or global drivers), helping reduce operating costs or forecast market trends more accurately. All the elements can be improved via mechatronics, which makes this technology critical for strategic and sustainable business development.

\subsection{The application of mechatronics in business strategy}

The role of various mechatronics-related technology (including artificial intelligence and embedded digital solutions) on business strategy can be interpreted from different perspectives: from the effectiveness of decisionmaking (while engaging and integrating employees of different hierarchy levels, along with other stakeholders); covering management aspects, such as organizing, coordinating, controlling/monitoring and motivating; and 


\section{INSIGHTS INTO REGIONAL DEVELOPMENT}

ISSN 2669-0195 (online) http://jssidoi.org/jesi/

2021 Volume 3 Number 3 (September)

http://doi.org/10.9770/IRD.2021.3.3(5)

finally with the interpretation of functions of various departments that are responsible for efficient strategy execution (such as Communication, Data Management, Business Intelligence, Marketing, Sales, R\&D, HR, Innovation, Production, and others). Hacklin et al. (2018) conducted qualitative research (14 cases and 68 interviews) within the ICT sector and demonstrated how business model innovation should be reshaped in order to strengthen the competitive advantages of a company: a continuous monitoring of limitations and opportunities of business strategies should be conducted, along with the adjustment of the weaker elements to better fit the value migration and competitive landscape among firms.

The efficiency figures of various departments should be tracked in order to optimize performance, reshape priorities, goals, and outcomes. For instance, Donat (2011) identified success factors of small businesses, such as flexibility, innovation, cost, and supply efficiency, while modern technology (including mechatronics) was considered to contribute to higher productivity as well as R\&D and human resource performance. Đặng Ngọc Quý (2018) emphasized the role of the high-tech and low-tech combination while combining experts from diverse industries and developing trans-disciplinary skills, thanks to digital technology solutions, which are critical to the communication and marketing areas. Thus, mechatronics can be useful in every department, management function, or business development stage, thanks to its power to help analyse and use data, assistance in decision-making and execution, and contributions to smoother, more interactive, and transactional communication among stakeholders.

Satalkina, L. \& Steiner, G. (2020) argue that digital technologies not only provide new business opportunities but are also disruptive and trigger new challenges. The authors underline three channels through which digital entrepreneurship can affect the whole innovation system: the digital business environment and infrastructure, attitudes, and perceptions as well as start-up ecosystem conditions. The authors also emphasize the role of the system of relationships, along with collaboration and social values. Such insights are in line with Jain's \& Yadav's (2017) ideas that organizational strategies should be centred on digital media devices and key strategic partnerships; however, it may significantly increase the expenditure lines. Organizations feel the pressure from other stakeholders to efficiently collaborate while using modern technologies and manage risks (making fast and effective decisions), which are important parts of any strategy (Ferguson et al., 2016). The 2018/2019 GEM report shows that the gig and shared-value economy emerge as new key elements of modern organizations in light of new technologies (such as artificial intelligence, digital hubs, robots, augmented reality, etc.), which in parallel help mitigate risks, create a synergy effect among stakeholders, and achieve a greater assortment of products and services.

The link between mechatronics and business strategy could be interpreted from the perspective of how much attention business strategies (from the corporate point of view) and theories (from the theoretical point of view) pay to modern technology (including mechatronics), which draw attention to the corresponding preconditions for leveraging the technology impact on business strategy success (such as $R \& D$ expenditure and culture, innovation climate, technological skills or the use of technology in communication with stakeholders). These aspects should manifest in strategy plans, reports, theories, innovation commercialization, and management models.

For instance, Giobanu and Neamtu (2017) indicate that innovation has become a compulsory precondition to flexibly react to the market volatility; thus, technological improvement affects the success of any entrepreneurial actions that are part of a strategy (they consider it to be an action plan).

In discussing digital technology within the Romanian entrepreneurial environment, the authors underlined adaptability and competitiveness (two strategy dimensions) as being affected via technological transformation to achieve the sustainable organic growth of a company. Focus group-based qualitative research led Giobanu and Neamtu (2017) to the conclusion that the success of technology-driven strategies depends on the adopted 


\section{INSIGHTS INTO REGIONAL DEVELOPMENT}

ISSN 2669-0195 (online) http://jssidoi.org/jesi/

2021 Volume 3 Number 3 (September)

http://doi.org/10.9770/IRD.2021.3.3(5)

leadership and management style, which requires account being taken of the diverse characteristics of generations, gender, and social trust.

In addition to the basic R\&D performance and necessary input for research activities, Perlser (2014) distinguishes the difference between technology and technology management and examines performance-oriented technology strategies through dimensions such as product development intensity and technology focus factors. After investigating technology-driven firms listed on the Johannesburg Stock Exchange (JSE), the author concludes that technology policy decisions among managers and leaders could significantly affect the success of a company; therefore, special attention should be paid to management team functions, while researcher empowerment, integration of $\mathrm{R} \& \mathrm{D}$ with other business units, and the corresponding $\mathrm{R} \& \mathrm{D}$ expenditure should be emphasized.

Within the Deloitte Insights Report 'Tech Trends 2020', innovation strategies are part of the link between innovation (including modern technology improvement) and business strategy: many technological innovations are oriented to ambient experiences, exponential intelligence, and quantum technology, while trust and risk management (including privacy, transparency, ethics, and security) in the context of emerging technologies emerge as important elements of the corporate strategies of modern companies. The use of technologies in developing and driving a business strategy is connected to core values and ethical/moral principles. Based on the Deloitte report (2020), IT solutions could help leaders and top managers to mitigate cyber risk and improve social trust among stakeholders. Various mechatronics-related technologies, such as AI, can help monitor how technology projects comply with the strategy (including project goals, outputs, and social value).

Some authors such as Muñoz et al. (2016) highlighted the role of the expected outcome of a business strategy as the main strategic orientation. While analysing the success of a Spanish pharmaceutical distribution firm and its IT development, the authors emphasized the importance of strategic targets related to customers/clients (which is related to marketing) and society (which is associated with social value). Having these strategic targets underlined, it is much easier to choose and adapt the technology to a business strategy. It is in line with the position of Wilburn and Wilburn (2018) that the combination of artificial intelligence, big data, and the Internet of Things (IoT) helps optimize business performance. Robots replace humans and enable products and services to be offered at lower prices, while employees become self-employed or start working, relying on temporary, one-off contracts, being involved in digital platforms and gigs. The emergence of mechatronics in business is a favourable factor and a new opportunity for some individuals, while others may need to completely change their specialization or seek governmental help.

While scrutinizing the connection between human resource strategies and technology in financial services, PWC researchers (2020) foresee the increasing role of technology in workforce productivity, a combination of HR technology strategy with overall business and talent strategies in areas such as recruitment, data management, communication, and employer brand promotion. Thus, mechatronics may help organizations access a sufficient supply of human resources with the right qualifications, experience, and performance level, particularly considering emerging new technologies. New technologies usher in an era of efficient risk and big data management, accompanied by cyber security and social value-added (Deloitte, $10^{\text {th }}$ Anniversary addition, 2019) that are important dimensions of a technology-based strategy. According to Accenture researchers (2019), while better understanding technology from the marketing pull perspective, companies may improve the percentage of loyal customers, while digital demographics may bring new business development opportunities.

New technologies directly influence human resource strategies; however, innovation processes from creative ideas to market entry and commercial value require investment in both technology and intellectual capital. Thus, new employees are becoming intermediaries between clientele/consumer and technologies. Based on KPMG (2019), about two thirds of HR specialists admit that HR's function is continuously evolving within this 


\section{INSIGHTS INTO REGIONAL DEVELOPMENT}

ISSN 2669-0195 (online) http://jssidoi.org/jesi/

2021 Volume 3 Number 3 (September)

http://doi.org/10.9770/IRD.2021.3.3(5)

technological time of change; human resource strategies are shifting towards a focus on such elements as business intelligence, artificial intelligence, predictive analytics, process automation.

Goren (2018) adds that to excel in management functions and business intelligence performance, it is particularly important to understand the context/intention of technology improvement and provide continuous care of the work-life balance at each strategy development stage. Udod et al. (2020) support such insights with an emphasis on emotional intelligence in helping leaders empower work environments via interpersonal relationships and conditions for creativity. According to Subramanian (2020), along with AI innovations and robotics, a broader set of emotional intelligence factors will be integrated into modern technology solutions, which may change the competition conditions in the market and may require better HR strategies and techniques.

According to Seok-Woo et al. (2013) a well-developed innovation climate and modern communication strategies may mitigate unpleasant risks and raise social trust levels among community members, while Uusi-Kakkuri (2017) associates the emergence of modern technologies with transformational leadership; thus, this dimension should be incorporated into business strategies. Jiang et al. (2017) and Aunjum et al. (2017) stated that organizations can evolve only via motivated employees, a well-established network of stakeholders (Yonazi et al. 2012), and happy citizens and customers (Gálvez-Rodríguez et al. 2016).

In addition to the specific development context of each economy and a company (Singh et al., 2015), modern technology can affect the development of social networks and social projects (Cartigny and Lord, 2017), while technology emerges as a key instrument to gather community and share resources. Transformational leadership (Husain, 2013), communication improvement strategies (Shanga et al., 2017), team building and training schemes (Luthra and Dahiya, 2015), and team performance (McEwan et al., 2017) can be improved by mechatronics, and they should be introduced to business strategies as outcomes, while modern technology should be indicated as an instrument for strategy execution and its improvement.

\subsection{Effectiveness and efficiency of mechatronics in business}

Companies use various business process optimization tools for such tasks as product development, delivery, planning, creative activities, and recruiting new employees. Business process optimization requires a set of outputs, such as error correction, waste avoidance, cutting unnecessary costs and/or enhancing the performance of various departments to reach strategic targets of a company. Haley Burton (2019) notes that there are three different techniques of business process optimization: business process management (BPM), business process automation, and robotic process automation (RPA). Each technique refers to how it helps a company improve various processes and reduce repetitive or inefficiently executed work while strengthening the competitive advantage of an organization.

Understanding modern technology trends enables individuals and companies to prepare for change and develop the skills necessary for future business development (Dyaksov, 2015). Many global business development drivers, such as social innovation, the shared value economy, or corporate social responsibility, become important focus areas for technology developers or users. According to the CSR interpretation of the Department of Trade and Industry in the United Kingdom (2018), corporate social responsibility represents integrity in fulfilling the corporate mission, engages stakeholders, creates social value, and gathers a community around various social challenges; thus, mechatronics must be sufficiently advanced to support all these global trends.

Carrolls (1979) introduced the Pyramid of Corporate Social Responsibility, which includes corporate citizenship, corporate sustainability, stakeholder management, environmental management, business ethics, and corporate social performance. Moreover, CSR provides major benefits in terms of risk assessment, cost reduction, capital allocation, customer relations management, human resource management, organizational sustainability, creativity, 


\section{INSIGHTS INTO REGIONAL DEVELOPMENT}

ISSN 2669-0195 (online) http://jssidoi.org/jesi/

2021 Volume 3 Number 3 (September)

http://doi.org/10.9770/IRD.2021.3.3(5)

innovativeness, and profitability. While offering a set of values to create a more united society, mechatronics can also affect the sustainability of an economic system. For instance, the emphasis on environmental protection helps businesses minimise energy usage; reduce waste; follow a more effective use of raw materials; cut the pollution rate; reduce costs; increase employees' efficiency, creativity, and work-life conditions; minimize risks; enhance the social image among stakeholders; and implement ethical and moral norms (Business Wales, 2020).

Social technologies are gaining in popularity among technology-driven businesses because social media has changed the way businesses develop and implement their strategies for sustainable and socially responsible growth, while the digital environment has created an opportunity to interact and communicate in a more transactional, creative, and intuitive way. Based on the Deloitte study 'Leading the Social Enterprise: Reinvent with a Human Focus' (2019b), it is possible to affect employees' dedication to their companies' strategies via creativity and innovation (as was claimed by 78 percent of workers), which is tightly related to the application of modern technologies.

Driven by the main vision of applying mechatronics to various business processes in order to improve the quality of new systems and products, mechatronics' main advantage is building innovative and profitable opportunities for enterprises to excel in manufacturing, production, or services, along with the accurate prototyping of operating systems or optimizing design in terms of a set of efficiency criteria, such as the use of raw materials and time (McHugh and Zhang, 2018). Thus, many companies know their strategic goals well but are not efficient in implementing their strategies while optimizing various processes and minimizing their inputs (Surbhi, 2018).

A mechatronics-inspired system design offers the flexibility to add elements, such as advanced user interfaces and safety features, which may significantly contribute to business effectiveness and efficiency. This modern technology also provides a certain user-friendly, easily applicable service, which facilitates various business functions; maximizes operational efficiency, productivity, and creativity; and makes business processes safer. When employees feel safe at work, they perform more effectively (Bastion Safety Solutions, 2018). Moreover, it can also encourage energy conservation (because different parts of a system can be shut off when not in use) or increase the flexibility and reliability in designing and using various products. According to Vista Industrial Products (2013), with the right knowledge and people, the implementation of mechatronics helps convert raw data to enable businesses to make the right decisions that in turn make business procedures more efficient and innovation projects more successful.

Along with a vast diversity of areas where mechatronics can be value-adding, the companies should not diminish the required inputs for its successful implementation: using mechatronics and automation systems could be one of the largest company's operating costs, along with the R\&D and HR expenditures (for the R\&D culture enhancement or trainings how to implement mechatronics in practice). An insufficient supply of R\&D experts or challenging adaptation of mechatronic techniques to employees of various generations can be a prohibiting factor for innovative companies (Czaja et al. 2006). From the work-life and social responsibility perspective, modern technologies have the capability to assist members of various generations in maintaining healthy and selfsufficient life (Geraedts et al. 2014). Thus, the use of mechatronics (in medicine or psychological assistance) has a crucial impact on both a company and a country through a social life of its citizens (Robinson et al. 2014). 


\section{INSIGHTS INTO REGIONAL DEVELOPMENT}

ISSN 2669-0195 (online) http://jssidoi.org/jesi/

2021 Volume 3 Number 3 (September)

http://doi.org/10.9770/IRD.2021.3.3(5)

Monitoring, data management, and business intelligence within various processes, according to the International Labour Organization (2017), become more important in tracking and optimizing the performance as well as helping decision-makers determine how a certain implemented mechatronic tool or system is used over time and track the feasibility of various activities. According to Dunn (2019), various monitoring and statistical tools help illustrate the dynamics of strategic results over time with charts or other visual means. Osman (2002) specifies both qualitative and quantitative methods of monitoring, which should be undertaken for regular 'health checks' of business processes on a daily, weekly, monthly, quarterly, or annual basis. To be sustainable and successful, companies need to apply effective and efficient mechatronics along with business intelligence (Clintock, 2019). According to Voehl (1995), improvement is driven by a continuous learning process; thus, modern technology can also assist educators and trainers.

In order to summarise the scientific literature review, accompanied by various corporate examples, the authors of the present publication developed the conceptual model at the meta level, which drew attention to the transformation of businesses from lower tech to higher tech at the micro and meso levels (horizontal arrow) and the shift of an economy from the efficiency to innovation-driven stage at the macro and international levels (vertical arrow). Within both transformation processes (micro/meso and macro/international), modern technology and innovation (including mechatronics with its characteristic of linking other technologies into hybrid digital solutions) emerges as a key driver for the transition from lower-tech to higher-tech business or from the efficiency-driven to the innovation-based economy.

It is interesting to note that technological development at both levels may face the challenge of education (either in number of graduates or specific knowledge necessary to effectively and efficiently apply mechatronics). According to Onkelinx et al. (2016), the level of human capital is a key driver for firms' internationalization. Moreover, the more technologically advanced and innovation-driven a business or an economy is, the more important social value-added is, which can be created through social innovation, spirituality, creativity, and perception/attitude.

Apart from focusing on improving the innovation process and efficiency (automation and production), more technologically advanced businesses and economies can focus more on the development of various hybrid solutions, which could help improve social well-being, work-life conditions, social trust, and synergy among stakeholders. It can also help fight various global challenges, such as climate change, pollution, or terrorism. The sooner an innovation-driven company or economy addresses the significance of emerging technology, the higher results they achieve from the process of digitalization (including digital marketing and video advertising) and mechatronics.

Business transformation through mechatronics is presented in Figure 1 below. 
INSIGHTS INTO REGIONAL DEVELOPMENT

ISSN 2669-0195 (online) http://jssidoi.org/jesi/ 2021 Volume 3 Number 3 (September) http://doi.org/10.9770/IRD.2021.3.3(5)

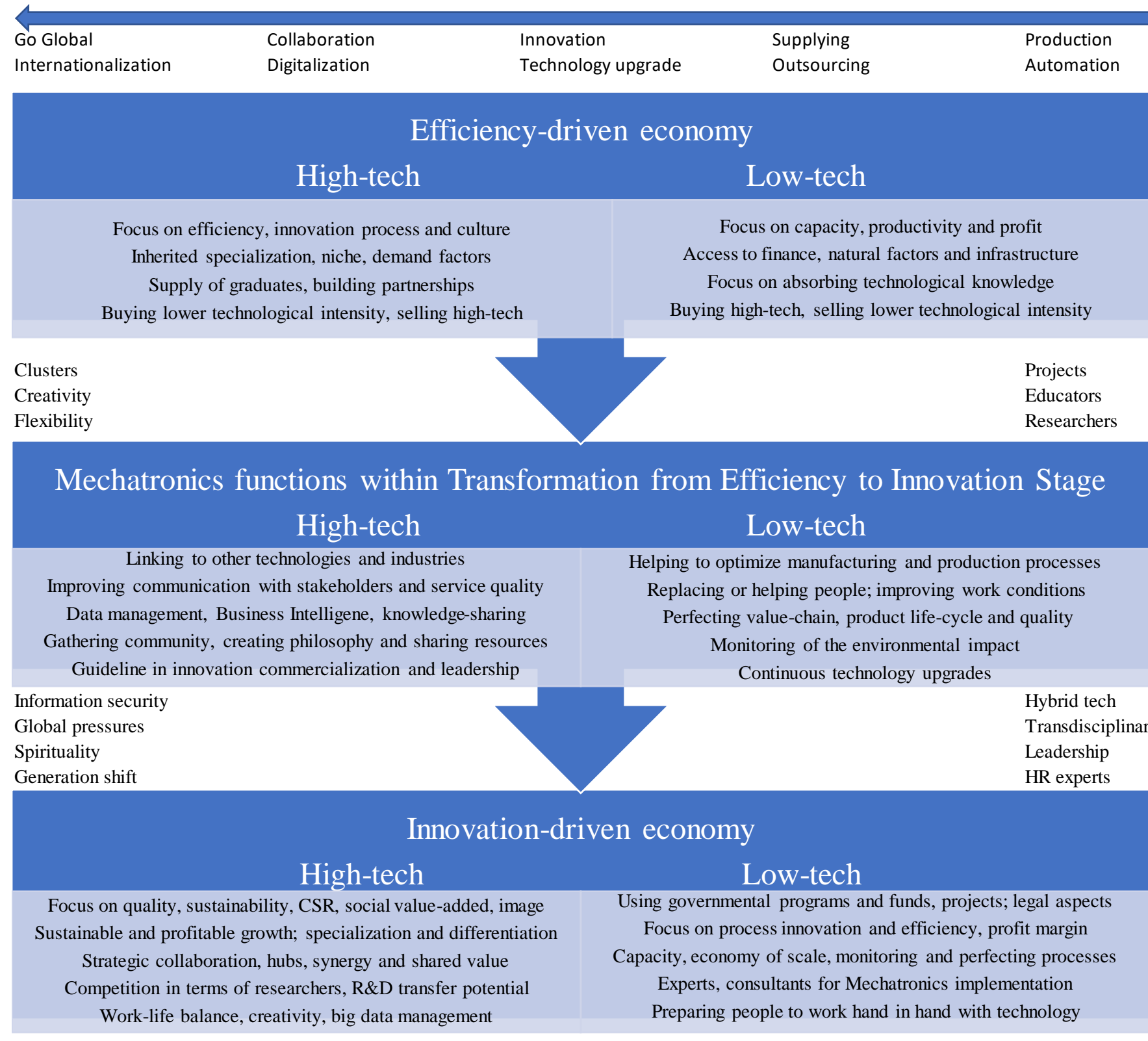

Social innovation

Perception

Tech vs. humans

Figure 1. Business transformation through mechatronics.

Source: authors' own figure, based on the literature review.

Based on the developed conceptual model, the transformation of lower-tech companies is centred on the development or enhancement of the transdisciplinary technology knowledge and leadership skills, while the HR department is critical in reshaping employee specializations while helping them work hand in hand with modern technology. Innovation-driven organizations emphasize positive externalities, such as social well-being, work-life balance, and a cleaner, healthier, and safer world. Thus, the more effective combination of high and low tech could help firms of lower technological intensity innovate, differentiate their product portfolio, increase efficiency, and unlock new social opportunities. Additionally, via digital hubs and mechatronics, lower-tech firms could participate in the decision-making, creativity enhancement, and innovation implementation process of high- 


\section{INSIGHTS INTO REGIONAL DEVELOPMENT}

ISSN 2669-0195 (online) http://jssidoi.org/jesi/

2021 Volume 3 Number 3 (September)

http://doi.org/10.9770/IRD.2021.3.3(5)

tech leaders, which could help high-tech firms improve product/service quality, free up cash for social initiatives, and serve the lower-tech clients as an innovation guideline for a project-driven learning process.

\section{Methodology}

In order to better measure the impacts of mechatronics on companies of diverse technological intensity, the methodology of the present paper is based on interviews with both high-tech managers (in the present publication - IT) and representatives of technologically less intensive companies (in the case of the present publication textile) which operate in Lithuania (a country transitioning from the efficiency to the innovation-driven category). The choice of the experts and the market was made in order to draw attention to the significance of the development stage of both the economy and company as well as to explain the multi-functionality and diverse application of mechatronics in various contexts and areas.

According to Global Entrepreneurship Monitor (GEM, 2017), efficiency-driven economies are driven by increasing competition, improving production processes and quality, and the development of an innovation climate, while innovation-driven economies are more knowledge intensive and the R\&D-based innovation service culture is rich and diverse. In both cases, mechatronics can add value; however, its role will manifest in different areas, depending on the competitive advantages and strategic targets of the analysed firms. Gregersen (executive director of MIT Leadership Center, 2017) highlighted new products, services, and processes that require the ability to absorb new ideas; however, the innovation implementation process is inseparable from the environment (Rogers and Shoemaker, 1971).

During the GEM membership period (2011-2014), Lithuania was an efficiency-driven economy with rather similar indicators to Latvian ones, which was marked by examples of innovation, such as the most powerful laser or the most resistant phone screens (investinlithuania.lt, 2019). According to the Department of Statistics of Lithuania (2018), every fourth student in Lithuania chose innovation-related studies.

Digitalization within various spheres calls for information and operating systems, while the field of IT and computer science require an adequate supply of innovation-related graduates. In parallel with 299 million euros dedicated to the R\&D infrastructure over the period 2012-2015, Lithuania allocated 679 million euros for higheducation enhancement during the period 2014-2020 (investlithuania.com, 2018). While occupying the $40^{\text {th }}$ place within the innovation index in 2018 (which is similar to the position of Poland $-39^{\text {th }}$, Slovakia $-34^{\text {th }}$ and Italy $31^{\text {st }}$ ), this Baltic county has a lot of potential to catch up in global innovation rankings if it uses mechatronics in innovation process management and finding the economic and social value in creative ideas (GEM, 2019).

In order to answer the research question how the potential of mechatronics in strengthening competitive advantages and creating value for the stakeholders of high-tech and technologically less intensive companies can be unleashed, first, the literature review focused on the importance of mechatronics/robotics in business processes, the main goals of the implementation of modern technologies, and the key reasons why companies fail to implement high technologies in business. The research was oriented to the comparison of previously conducted research on mechatronics' effectiveness/efficiency as well as the determination of the competitive advantages companies could gain while having various mechatronics tools implemented successfully; the comparison of the strategies in use among high-technology businesses and technologically less intensive companies helped choose and use a particular modern technology or a system of mechatronics tools.

To support the conceptual model, which derived from the literature review, as well as prepare the questionnaire for semi structured experts' interviews, a set of similar studies on mechatronics' effectiveness and efficiency was compared (see Table 1). 


\section{INSIGHTS INTO REGIONAL DEVELOPMENT}

ISSN 2669-0195 (online) http://jssidoi.org/jesi/

2021 Volume 3 Number 3 (September)

http://doi.org/10.9770/IRD.2021.3.3(5)

Table 1. Research cases to back the methodology choice

\begin{tabular}{|l|l|l|l|l|l|}
\hline Author & Year & Method & Purpose & Results & Link to the present research \\
\hline $\begin{array}{l}\text { Kashan } \\
\text { Pirzada \& } \\
\text { Ahnir }\end{array}$ & 2013 & $\begin{array}{l}100 \\
\text { employee } \\
\text { s of } \\
\text { Pakistan, } \\
\text { Suzuki } \\
\text { Motor }\end{array}$ & $\begin{array}{l}\text { To identify factors } \\
\text { connecting modern } \\
\text { technology with the } \\
\text { corporate strategy, } \\
\text { effects on the } \\
\text { company's } \\
\text { performance. }\end{array}$ & $\begin{array}{l}\text { Manufacturing, designing, planning, } \\
\text { research, and engineering directly } \\
\text { contribute in selecting the technology, } \\
\text { followed by the implementation } \\
\text { process. }\end{array}$ & $\begin{array}{l}\text { Both studies identify the value- } \\
\text { added of modern technology in } \\
\text { business processes; our } \\
\text { publication is based on } \\
\text { qualitative expert interviews. }\end{array}$ \\
\hline $\begin{array}{l}\text { Brown and } \\
\text { Sikes }\end{array}$ & 2012 & $\begin{array}{l}\text { Survey of } \\
1469 \\
\text { high-tech } \\
\text { firms }\end{array}$ & $\begin{array}{l}\text { To scrutinize the role of } \\
\text { IT in digital business } \\
\text { initiatives. }\end{array}$ & $\begin{array}{l}\text { Executives identified organizational } \\
\text { structures and IT systems as the key } \\
\text { challenges to unlock big data } \\
\text { opportunities. }\end{array}$ & $\begin{array}{l}\text { Companies are obliged to invest } \\
\text { in the improvement of business } \\
\text { processes, where mechatronics } \\
\text { plays a crucial role. }\end{array}$ \\
\hline $\begin{array}{l}\text { Informa's } \\
\text { Industry } \\
\begin{array}{l}\text { Week; } \\
\text { Jitterbit and } \\
\text { Epicor }\end{array}\end{array}$ & 2019 & $\begin{array}{l}\text { Market } \\
\text { survey }\end{array}$ & $\begin{array}{l}\text { To examine the } \\
\text { progress of the } \\
\text { companies while } \\
\text { adopting the fourth } \\
\text { industrial revolution. }\end{array}$ & $\begin{array}{l}\text { Most manufacturing and supply chain } \\
\text { companies are moving to the industrial } \\
\text { revolution via continuous learning how } \\
\text { to choose and apply modern } \\
\text { technologies. }\end{array}$ & $\begin{array}{l}\text { Since mechatronics is a new } \\
\text { sector, many companies are still } \\
\text { learning how to efficiently } \\
\text { implement this technology. }\end{array}$ \\
\hline
\end{tabular}

Source: authors' own table, based on the literature review.

Unlike the compared methodologies, our research relied on the qualitative method because effectiveness and efficiency entail many holistic technology aspects, diverse management, leadership, communication styles, and digital tools crossing various hierarchy levels and value-chain points in both high-technology and technologically less advanced companies. Most of the mechatronic-related information is top management material, which is related to strategic decision-making, the monitoring of which consists of both economic and social value-added criteria.

As indicated in Appendix 1 the questionnaire contained questions of two different scales: to identify the main factors that encourage or prohibit the mechatronics application process and affect the efficiency and effectiveness of business processes, a scale from 1 to 9 or brackets of percentage values were used; the experts were also asked to indicate the main strategic departments and investment allocation areas. In total, experts from eight different companies were interviewed: half specialized in a high-technology business sphere (information technology), while the other half of the experts represented a technologically less intensive industry (textile) that should use high-technology tools or systems. Two experts' coding criteria (education and working experience) were used to better understand the experts' perception of the mechatronics implementation process; a few questions were formulated to understand the value-added and future development trends of mechatronics; four questions were related to the characteristics of the selected technology and its implementation process; the last question helped us to understand the competitive advantages of companies if the mechatronics technology is implemented.

\section{Assessment: efficiency and effectiveness of mechatronics in Lithuanian IT and textile companies}

Building on the research in the literature review and applying a few comparative analysis criteria, such as hightech business experience versus the experience in technologically less advanced companies or the perception and attitude of young (high-tech experts were relatively younger) versus senior respondents (older people tend to choose technologically less intensive companies), the mechatronics application effectiveness/efficiency was interpreted in the context of two specific industries.

The relevance of the research question was confirmed by the fact that neither any the interviewees from hightechnology companies nor from technologically less advanced companies had a degree in mechatronics, which is 


\section{INSIGHTS INTO REGIONAL DEVELOPMENT}

ISSN 2669-0195 (online) http://jssidoi.org/jesi/

2021 Volume 3 Number 3 (September)

http://doi.org/10.9770/IRD.2021.3.3(5)

also in line with the research conducted by other scholars, who revealed an insufficient number of graduates for mechatronics implementation across various businesses.

As indicated in Appendix 2, half of the respondents from the information technology industry had from 1 to 4 years of working experience with a high-tech content, and the other half indicated 5 to 9 years of experience of working with mechatronics-related technology. The experts from the companies of lower technological intensity belonged to two categories: half of the experts had no experience working with high technology, one had the experience up to 4 years, and the other one possessed at least 10 years of experience of working with high technologies. Taking into account that only a minority of respondents had over 10 years of experience in mechatronics-related areas, the application of technological mechatronics-based innovation should be centred on the continuous competence enhancement and lifelong learning, which is in line with scholars' insights. Nonetheless, the necessity to have a degree in mechatronics was mentioned by only half of the respondents, who prioritised the personal characteristics and skills for a position. On the contrary, a few experts with more solid experience (at least 36 years old) admitted that a high-tech related degree may be an advantage in terms of technological and engineering knowledge.

Furthermore, all the experts, regardless of the technological intensity of their company, stated that the main trigger for applying mechatronics technology in business is the increase in the effectiveness and efficiency via cost optimization. However, only one respondent pointed out the value of innovativeness and creativity. The representatives of high-tech companies underlined two main modern technologies (cloud servers for storing data and business intelligence for analysing data), while representatives of the technologically less advanced companies highlighted machinery that allowed the process automation.

The implication that the type of implemented technology in business processes depends on a company's specialization and its unique strategic motives was dominant in both high-tech and low-tech firms. The respondents reached an agreement while indicating the two key challenges of mechatronics implementation in their business procedures, although the cost base was identified as the main obstacle. What is more, regardless of what kind of mechatronics was applied, representatives of both industries noted that it was hard to find specialists who have the required knowledge for efficient mechatronics usage. For instance, the maintenance of implemented technologies was highlighted by both the textile and IT managers, although quality and errors monitoring required profound transdisciplinary knowledge and a rather holistic understanding of the whole process.

While forecasting and foreseeing mechatronics' application success, the respondents concluded that the significance of process automation is a converging factor across various industries, notwithstanding their rather different positions in terms of competitive advantages: the IT experts noted the increasing quality of their service through simultaneous data analysis and its usage in decision-making (as well as effective allocation of investments), while the textile experts emphasized the efficiency of manufacturing, which led to higher sales and safer working conditions. Later, all the IT respondents expressed the relevance of the R\&D department in terms of outputs. According to nearly all respondents, this department deserves from $20 \%$ to $35 \%$ expenditure of revenue, followed by another important department of technology and innovation (more than half of the respondents would invest less than $20 \%$ of their revenue). While tackling the marketing function, this department was described as a key to success for high-tech companies. More than half of the interviewees indicted that the investment from 20\% to $35 \%$ would be appropriate, while two experts allocated more than $35 \%$ of their revenue to marketing. Although the reviewed studies on mechatronics application were centred on knowledge and human capital, the human resource department seemed to be less identified than the previously mentioned ones: the IT experts agreed to invest only $10 \%$ of their revenue into new HR initiatives.

The distribution of the experts' responses in the firms of somewhat lower technological intensity were rather mixed: the R\&D/technology and innovation department was not significantly emphasized, as the experts would 


\section{INSIGHTS INTO REGIONAL DEVELOPMENT}

ISSN 2669-0195 (online) http://jssidoi.org/jesi/

2021 Volume 3 Number 3 (September)

http://doi.org/10.9770/IRD.2021.3.3(5)

invest only $10 \%$ or less of their revenue in this area. The marketing department seemed to be even more important than among the high-technology firms; all the experts indicted that the investment of at least $20 \%$ would be necessary to successfully grow. In addition to mixed results regarding the R\&D department, the efforts to improve the human resource department in technologically less advanced companies were perceived differently: half of the respondents indicted from 5\% to $10 \%$ of revenue should be devoted to this area, but there were a few respondents who claimed that it would be important to invest at least $20 \%$ in order to make a business of lower technological intensity sustainable (Table 2).

Table 2. Investment rates to different business departments among high-tech and lower-tech companies (indicated by experts' responses as a percentage of revenues)

\begin{tabular}{|c|c|c|c|c|}
\hline & R\&D Department & $\begin{array}{l}\text { Department } \\
\text { Technology } \\
\text { Innovation }\end{array}$ & $\begin{array}{l}\text { Marketing } \\
\text { Department }\end{array}$ & $\begin{array}{l}\text { Human Resources } \\
\text { Department }\end{array}$ \\
\hline High-tech companies & From $20 \%$ to $35 \%$ & Less than $20 \%$ & $\begin{array}{l}\text { From } 20 \% \text { to } 35 \% \text {, } \\
\text { while } 2 \text { experts } \\
\text { allocated more than } \\
35 \%\end{array}$ & Less than $10 \%$ \\
\hline Lower-tech companies & Less than $10 \%$ & Less than $10 \%$ & At least $20 \%$ & $\begin{array}{l}\text { From } 5 \% \text { to } 10 \% \text {, } \\
\text { while a few } \\
\text { respondents allocated } \\
\text { at least } 20 \%\end{array}$ \\
\hline
\end{tabular}

Source: authors' own figure, based on experts' interviews.

Notwithstanding that marketing is more indicated among key departments in low-tech companies, the technology and innovation functions seem to be diminished in the textile firms, compared to high-tech businesses. What is more, technologically less advanced companies would be more willing to invest in the human resources department and other fields of operations, which indicates that high technology companies with their prioritized innovation function already have the innovation culture established along with entrepreneurship behaviour patterns. The technologically less advanced firms follow efficiency-driven behaviour patterns (with a strong role for the HR department in creating an adequate innovation climate), in spite of the fact that all the investigated companies operate in the same country (transitioning from the efficiency to the innovation-driven category).

The experts' perception with regards to the main effects of mechatronics in business processes (where 1 refers to 'not important at all' and 9 means 'particularly important') depends on their operational fields. Technologically less advanced companies highlighted brand value and social image as impacts of mechatronics nearly twice as much as high-tech companies, while social value-added and social innovation were more important among hightech companies. Although mechatronics/robotics could play a critical role in environmental protection, which can emerge as a key impact of mechatronics, the average experts' response from both industries was lower than 4, which means that experts diminished the role of mechatronics in solving environmental challenges or it was not part of their strategies.

Meeting the expectations of employees and business partners via modern technologies was ranked 7 out of 9 in both categories from the respondents. These numbers implied that regardless of technological intensity, good relationships inside and outside a company as well as the synergy effect among business partners could be achieved via mechatronics, which could play a significant role in making a business effective and efficient. The transformation style of communication inside and outside a company was highlighted by both IT and textile experts (high-tech companies gave this factor a value of 8.25 and companies of lower technological intensity considered it the second most important factor). 


\section{INSIGHTS INTO REGIONAL DEVELOPMENT}

ISSN 2669-0195 (online) http://jssidoi.org/jesi/

2021 Volume 3 Number 3 (September)

http://doi.org/10.9770/IRD.2021.3.3(5)

No matter what business sphere a company operates in, mechatronics can play a significant role in communication and can have an impact on productivity, employee satisfaction, revenue growth, and profit margins. A surprising result was seen with regards to the importance of mechatronics in brainstorming, generating new ideas, running innovation projects, or simply commercializing innovative ideas: it had the lowest average value of 2.63 among experts who represented technologically less intensive businesses, while the high-tech experts rated it a value of 5.88, which led to the conclusion that the high-technology companies were more willing to apply various forms of mechatronics while running new innovation activities. While making a company more sustainable, the promotion of knowledge sharing and innovation implementation would be more beneficial for high-tech firms; goods and services should be affordable and accessible to both types of companies (7.88 and 6.5 in technologically less advanced and high-tech firms respectively) (see Figure 2).

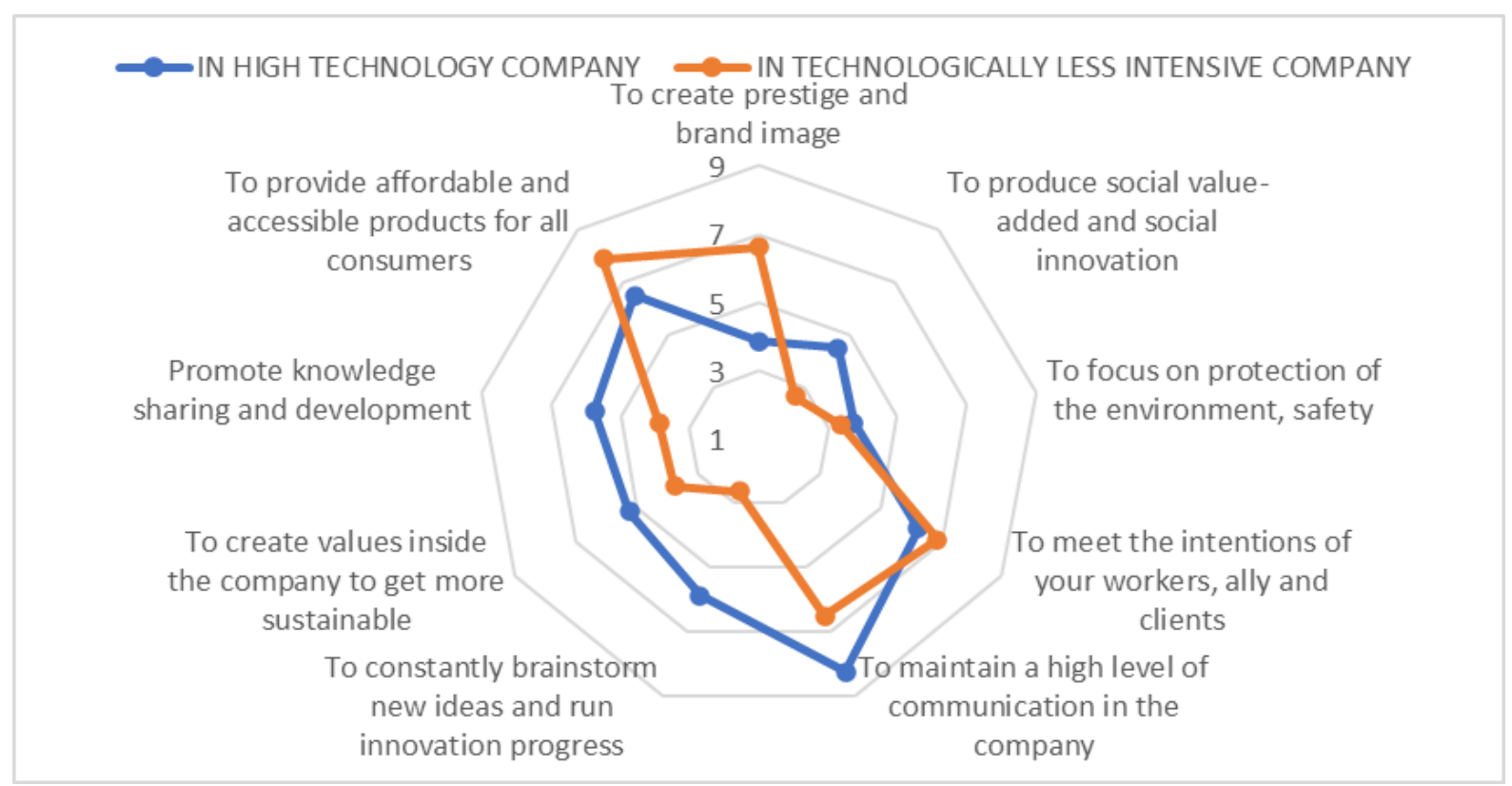

Figure 2. The impacts of mechatronics in high-tech and lower technological intensity firms Source: authors' own figure, based on experts' interviews.

After we interviewed experts from the high-tech and technologically less advanced firms, we were able to underline a set of pertinent implications. A certain qualification/degree in a mechatronics-related area is an advantage to high-tech firms although not compulsory. The application of mechatronics helps increase efficiency; however, this technology can diminish the profit margin due to the high cost base, insufficient knowledge, and lack of specialists. After implementing mechatronics technology, a company needs an expert to monitor the effectiveness and efficiency of the implemented systems. The experts agree that the automation of processes is inevitable in the future; however, the companies of lower technological intensity tend to focus more on the profitability of their businesses, while high-tech companies care about the well-being of their employees and social value-added.

Moreover, good communication inside and outside a company is crucial to successfully compete in the market. Applying mechatronics is accompanied by potential risks, such as a high cost base, scrutiny regarding information security or, a lack of labour supply; however, diminishing the role of mechatronics may jeopardize the sustainability and long-term value-added of the analysed firms (Figure 3). 


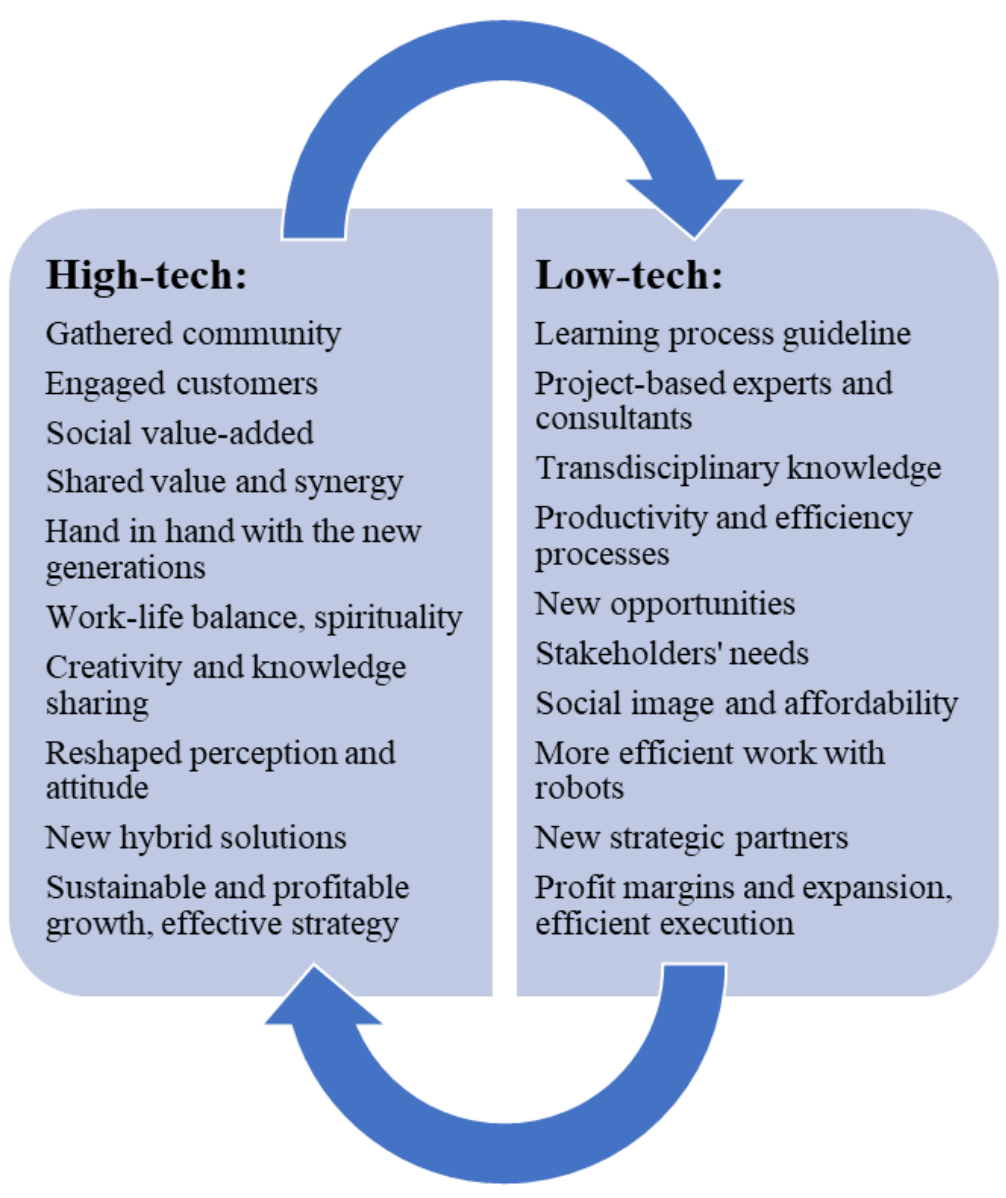

Figure 3. Advantages of mechatronics within high- and low- tech combination Source: authors' own figure, based on experts' interviews.

As illustrated in the model of advantages of mechatronics within the combination of high and low tech, both hightech companies and technologically less advanced firms have the potential to get significant value from mechatronics, which is in line with the conceptual model of business transformation via mechatronics. Within the model of advantages, the high- and low- tech combination happens through strategic collaboration, which can be improved thanks to mechatronics. Moreover, collaboration among companies of different technological intensity may lead to faster transition of the economy into the innovation-driven stage, as both categories of businesses can strengthen their competitive advantages via mutual synergy effects, smoother communication, and trust. Therefore, the combination policy would be particularly useful considering technological evolution if enough experts with transdisciplinary and specific technology knowledge are available. Helping companies prepare employees for new roles in the link between humans and robots will contribute to both social well-being at the macro and international level and better work-life balance at the micro and meso levels. 


\section{Recommendations}

To successfully operate in the field of high-tech firms, a degree in any high technology field is counted as an advantage; however, the focus should be on qualifications.

The main goal of applying mechatronics in business is increased efficiency, which is an important part of any business strategy.

Key obstacles in the application of mechatronics in business are high expenditure lines and insufficient employee qualifications, while digital communication platforms and shared value economy principles can help mitigate risks, lower costs, and leverage mechatronics' potential.

In addition to choosing the right mechatronics tool, a company needs to have enough experts to adjust the organizational climate, train people, and be responsible for monitoring and analysing the usage of the implemented technology.

Mechatronics helps develop and execute an effective/efficient strategy which leads to business performance optimization.

Technologically less intensive companies tend to focus more on the profitability of their businesses, while hightechnology companies equally care about economic and social value-added, including the well-being of their employees and the environment overall.

Regardless of the business operation field, mechatronics can help improve communication inside and outside a company, which is critical to compete in the market.

Mechatronics can help collect and analyse data, recruit the necessary specialists, and interactively communicate inside and outside the organization while engaging stakeholders in the decision-making process, along with strategy execution, employees' performance improvement, and monitoring.

Mechatronics can lead to the success of various departments, management functions, and efficiency at different development stages.

\section{Conclusions}

Mechatronics as a field of science brings various technologies under one umbrella, such as control engineering, computer technology, mechanical engineering, and electronic engineering. If businesses are willing to increase the efficiency and effectiveness of business processes, the demand factors for this modern technology are satisfactory. Apart from an effective selection of a certain mechatronics instrument, the most appropriate business optimization technique should be applied and the progress should be ingeniously monitored in order to increase the effectiveness and efficiency of business procedures (while reducing operational costs and maximize outputs).

Along with the implementation of mechatronics tools, the combination of modern technologies such as business intelligence, artificial intelligence, augmented reality, and others is necessary to support business strategies. Within a vast spectrum of functions, from big data management to increased operational efficiency, the combination of mechatronics with innovative technologies allows a firm to gain competitive advantages in complex markets. Even though it is crucial to monitor the implemented technique, the lack of experts with the 


\section{INSIGHTS INTO REGIONAL DEVELOPMENT}

ISSN 2669-0195 (online) http://jssidoi.org/jesi/

2021 Volume 3 Number 3 (September)

http://doi.org/10.9770/IRD.2021.3.3(5)

knowledge to lead and supervise the process is an obstacle for both high-tech and lower-tech firms, which is in line with the scientific literature review results.

After comparing the answers of respondents of high-tech and technologically less advanced companies, a distinctive difference between strategic priorities and departmental functions when applying mechatronics was identified: efficiency-oriented textile firms try to create innovation processes and implement the communication style that are already present in high-tech firms, although they both operate in the same Baltic market. Therefore, the activities of HR and marketing departments are oriented to strengthening the innovation culture.

Along with utilizing the sufficient supply of graduates who can contribute to the mechatronics application process, before implementing the mechatronics technology, every organization should prepare an ingenious strategy which contains clear strategic goals, efficiency criteria/KPIs, outputs, and the tactics behind each goal. Although scholars often emphasized the environmental impact of mechatronics, the interviewed IT experts did not emphasize this contribution despite their profound knowledge on the subject (this may be related to their strategic orientation). The experts from the technologically less advanced companies did not possess sufficient transdisciplinary knowledge, which can explain the lack of attention to various sustainability aspects (for instance, social value-added in terms of waste reduction or positive environmental impacts). Monitoring and data analysis tools are emphasized by the respondents of both high-tech and technologically less advanced companies via knowledge-sharing, lifelong learning, and creativity enhancement. Understanding the characteristics of mechatronics application in high-tech and lower-tech sectors is crucial for a country which is transitioning from the efficiency to the innovation-driven stage: the combination of the best experiences of industries of different technological intensity could help companies more readily achieve a synergy effect and help them understand the market trends and consumer expectations via digitalization, productivity, creativity, strategic collaboration, and community gathering.

\section{References}

Aaslaid, K. (2018). 50 Examples of Corporations That Failed to Innovate. Valuer's AI platform. Available Online: https://valuer.ai/blog/50-examples-of-corporations-that-failed-to-innovate-and-missed-their-chance/

Accenture (2019). The post-digital era is upon us: are you ready for what's next: Accenture Technology Vision 2019. Available online: https://www.accenture.com/t20190304T094157Z w /us-en/ acnmedia/PDF-94/Accenture-TechVision-2019-Tech-Trends-Report.pdf

Arkin, R. C. (2000). Behavior-based Robotics. Intelligent Robotics and Autonomous Agents series, a Bradford Book; third printing, 2000 edition (May 22, 1998), 491 p. ISBN-10: 0262011654, ISBN-13: 978-0262011655

Asimov, (1950). Runaround. I, Robot (The Isaac Asimov Collection ed.). New York City: Doubleday. p. 40. ISBN 0-385-42304-7.

Avgoustinov, N. (2007). Modelling in Mechanical Engineering and Mechatronics, Springer, 226 p. ISBN-13: 978-1846289088, ISBN-10: 1846289084

Badzinska, E. (2019). The Concept of Technological Entrepreneurship: The Example of Business Implementation. Entrepreneurial Business and Economics Review, Vol. 4, No. 3, pp. 57-72 DOI: 10.15678/EBER.2016.040305

Bekey, G.; Ambrose, R.; Kumar, V.; Lavery, D.; Sanderson, A.; Wilcox, B.; Yuh, J.; Zheng, Y. (2008). Robotics: State of The Art and Future Challenges, 152 p. DOI: $\underline{10.1142 / P 542}$

Bishop, R. H. (2002). The Mechatronics Handbook, ISBN 9780429115004, 1272 p. https://doi.org/10.1201/9781420042450

Bishop, R.H. (2006). Mechatronics an Introduction. eBook Published 19 December 2017, Imprint CRC Press, eBook ISBN 9781315220574, 307 p. DOI: 10.1201/9781420037241 


\section{INSIGHTS INTO REGIONAL DEVELOPMENT}

ISSN 2669-0195 (online) http://jssidoi.org/jesi/

2021 Volume 3 Number 3 (September)

http://doi.org/10.9770/IRD.2021.3.3(5)

Bishop, R.H. (2007). Mechatronic Systems, Sensors, and Actuators. $2^{\text {nd }}$ edition, published November 19, 2007 by CRC Press, 692 p. ISBN 9780849392580

Bolton, W. (1995). Mechatronics: Electronic Control Systems in Mechanical Engineering, Harlow, Essex, England; New York: Addison Wesley Longman, 392 p., ISBN 0582256348

Botea, A.; Kishimoto, A.; Nikolova, E.; Braghin, S.; Berlingerio, M.; Daly, E. (2019). Computing multi-modal journey plans under uncertainty, Journal of Artificial Intelligence Research, Vol. 65, No. 1, pp. 633-674, DOI: 10.1613/jair.1.11422

Brown, B.; Sikes, J. (2012). Minding Your Digital Business. McKinsey Global Survey Results. McKinsey and Company Research Results. Available Online: https://www.mckinsey.com/business-functions/mckinsey-digital/our-insights/minding-your-digital-business-mckinseyglobal-survey-results

Braga, N. C. (2001). Robotics, Mechatronics, and Artificial Intelligence, 336 p. ISBN: 9780750673891, eBook ISBN: 9780080516387, https://www.elsevier.com/books/robotics-mechatronics-and-artificial-intelligence/braga/978-0-08-051638-7

Burstein, F.; Holsapple, C.W. (2008). Handbook on Decision Support Systems 2, 798 p. ISBN 978-3-540-48716-6, DOI: 10.1007/978-3540-48716-6

Burton, H. (2019). Achieve end-to-end success with business process automation tools. Nintex papers. Available Online: https://www.nintex.com/blog/achieve-end-to-end-success-with-business-process-automation-tools/

Business Wales (2018). Protecting the environment. Available Online: https://businesswales.gov.wales/zones/corporate-socialresponsibility/environment/simple-ways-save-energy

Bastion Safety Solutions (2018). Top 10 Reasons - Why workplace safety is Important? Available Online: https://medium.com/@BastionSafe/top-10-reasons-why-workplace-safety-is-important-8797c978e1f9

Carroll, A.B. (1979). Three-Dimensional Conceptual Model of Corporate Social Performance, Academy of Management Review, Vol. 4, No. 4, pp. 497-505. DOI: $10.2307 / 257850$

Carini, C.; Comincioli, N.; Poddi, L.; Vergalli, S. (2015). Measure the Performance with the Market Value Added: Evidence from CSR Companies. Social Marketing Quarterly, Vol. 21, No. 3. DOI: 10.1177/1524500415595208smq.sagepub.com

Control Systems Inc (2020). Company's info. Available online: https://www.controlsystemsinc.net/index.html

Czaja, S.J.; Charness, N.; Fisk, A.D.; Hertzog, C.; Nair, S.N.; Rogers, W.A.; Sharit, J. (2006). Factors predicting the use of technology: findings from the Center for Research and Education on Aging and Technology Enhancement. Psychol Aging, Vol. 21, No. 2, pp. 333-52. DOI: $\underline{10.1037 / 0882-7974.21 .2 .333}$

Deloitte (2019a). 10th Anniversary addition, $142 \quad$ p. Available online: https://www2.deloitte.com/content/dam/Deloitte/br/Documents/technology/DI_TechTrends2019.pdf

Deloitte (2019b). Leading the social enterprise: Reinvent with a human focus. Eddited by Kaji, J.; Hurley, B.; Gangopadhyay, N.; Bhat, R.; Khan, A. 112 p. Available Online: https://www2.deloitte.com/content/dam/insights/us/articles/5136 HC-Trends-2019/DI HC-Trends2019.pdf

Deloitte Insights (2020). Tech Trends 2020, 132 p. Available Online: https://www2.deloitte.com/us/en/insights/focus/tech-trends.html

Department of Statistics of Lithuania (2018). Development of Innovation Activity, Available online: https://osp.stat.gov.lt/informaciniaipranesimai?articleId $=5552549$

Diaz, J.E.S.; Rudolf, T.M. (2019). Path Planning Based on an Artificial Vision System and Optical Character Recognition (OCR). Proceedings of the 2nd International Conference on Control and Computer Vision, pp. 33-37, https://doi.org/10.1145/3341016.3341034

Donat, B. (2011). Impact of Technology on the Business Strategy Performance Relationship in Building Core Competence in Uganda Small Medium Enterprises (SME's). Proceedings of the 7th International Conference on Innovation \& Management, 5p. https://www.pucsp.br/icim/ingles/downloads/papers_2010/part_1/Impact\%20of\%20Technology\%20on\%20the\%20Business \%20Strategy\% 20Performance.pdf

Dorf, R. C. (2004). The Engineering Handbook Hardcover, CRC Press, 3080 p. ISBN-10: 0849315867, ISBN-13: 978-0849315862 


\section{INSIGHTS INTO REGIONAL DEVELOPMENT}

ISSN 2669-0195 (online) http://jssidoi.org/jesi/

2021 Volume 3 Number 3 (September)

http://doi.org/10.9770/IRD.2021.3.3(5)

Dunn, K. (2020). Process Improvement Using Data. 417 p. Available Online: https://learnche.org/pid/PID.pdf

Dyaksov, P. (2015). Why should business be socially responsible? Available Online: https://dyaksov.com/en/entrepreneurship/why-shouldbusiness-be-socially-responsible/

Eckert, V.H.; Loop, P.; Berlin, B. (2017). How can boards tackle the Essential Eight and other emerging technologies? PwC US and Global New Business Leader, 8 p. Available online: https://www.conexxus.org/sites/default/files/book_files/essential-emerging-technologiescorporate-boards.pdf

Eisenträger, M.; Adler, S.; Kennel, M.; Möser, S. (2018). Changeability in Engineering. Engineering Technology and Innovation (ICE/ITMC), IEEE International Conference, pp. 1-8 DOI: 10.1109/ICE.2018.8436295

Englisch, P.; Smith, M.; Firnges, A. (2019). Using Essential Eight Technologies to advance digital transformation (2019). Available Online: https://www.pwc.com/gx/en/services/entrepreneurial-private-business/eight-technologies-to-advance-digital-transformation.html

English, L. (2005). Business Intelligence Defined. Beye Network. Available Online: http://www.b-eye-network.com/view/1119

Ferguson, J.; Ronayne, P. and Rybacki, M. (2016). Comparing Leadership Challenges: Civil Service vs. Private Sector. Centre for Creative Leadership, White Paper Part 2 in a 3-Part Series, p. 20: https://www.ccl.org/wpcontent/uploads/2016/02/ComparingLeadershipChallenges.pdf

Fluor (2020). Company’s info. Available online: https://www.fluor.com/

Fournier, G. (2017). The new mobility paradigm: transformation of value chain and value proposition through innovations. in Attias, D. (Ed.): The Automobile Revolution, Springer, Pforzheim. DOI: 10.1007/978-3-319-45838-0_3, Print ISBN 978-3-319-45837-3

Frank, A.G.; Dalenogare, L.S.; Ayala, N.F. Industry 4.0 technologies: Implementation patterns in manufacturing companies. International Journal of Production Economics, Elsevier, vol. 210(C), pp. 15-26. DOI: 10.1016/j.ijpe.2019.01.004

GEM (2011-2020). Global Annual Report. Available online: https://www.gemconsortium.org/

GEM (2014). National Data for Lithuania. Available online: https://www.gemconsortium.org/

GEM (Global Entrepreneurship Monitor) by Bosma, N.; Kelley, D. (2019). 2018/2019 Report. Available online: https://www.gemconsortium.org/

Geraedts, H.A.E.; Zijlstra, W.; Zhang, W.; Bulstra, S.; Stevens, M. (2014). Adherence to and effectiveness of an individually tailored home-based exercise program for frail older adults, driven by mobility monitoring: design of a prospective cohort study. BMC Public Health, Vol. 14, No. 570, DOI: 10.1186/1471-2458-14-570

Global Economic Forum (2018). The Global Competitiveness Index 2017-2018 edition, Report for Lithuania, Available online: http://www3.weforum.org/docs/GCR2017-2018/03CountryProfiles/Standalone2-

pagerprofiles/WEF GCI 20172018 Profile Lithuania.pdf

Global Entrepreneurship Monitor by Bosma, N.; Kelley, D. (2019). 2018/2019 Report. Available online: https://www.gemconsortium.org/

Global Innovation Index (2018). Dataset: CountryEconomy.com, Available online: https://countryeconomy.com/government/global$\underline{\text { innovation-index/lithuania }}$

Giobanu, O. G.; Neamtu, D. M. (2017). The impact and importance of new technologies in business development in context of economic diversity, Open Gruyter, Proceedings of the 11th International Conference on Business Excellence, pp. 698-710, DOI: 10.1515/picbe-20170074, ISSN 2558-9652

Goren, L. (2018). Ten Strategies for Building Emotional Intelligence and Preventing Burnout. Fam Pract Manag. Vol. 25, No. 1, pp.11-14, Available Online: https://pubmed.ncbi.nlm.nih.gov/29314808/

GOV.UK (2018). Guideline paper. Corporate Social Responsibility. Available Online: https://www.gov.uk/government/news/ourcommitment-to-corporate-social-responsibility-csr

Gregersen, H. (2017). Asking the Right Questions. In Charles Schwab White Paper: Examining the Power of Questions, Boston, MA: 2017. Available Online: https://mitsloan.mit.edu/faculty/directory/hal-gregersen 


\section{INSIGHTS INTO REGIONAL DEVELOPMENT}

ISSN 2669-0195 (online) http://jssidoi.org/jesi/

2021 Volume 3 Number 3 (September)

http://doi.org/10.9770/IRD.2021.3.3(5)

Hacklin, F.; Bjorkdahl, J.; Wallin, M. W. (2018). Strategies for business model innovation: how firms reel in migrating value. Long Range Planning, Vol. 51, pp. 82-110. DOI; 10.1016/j.lrp.2017.06.009

Hartmann, H.; Schautt, M.; Pascucci, A.; Gombert, B. (2002). eBrake® ${ }^{\circledR}$ - The Mechatronic Wedge Brake. SAE Technical Paper, No. 2582, https://doi.org/10.4271/2002-01-2582

Hammer, M.; Champy. J. (2006). Reengineering the corporation: a manifesto for business revolution. Collins Business Essentials. Harper Business; Revised, Updated edition, 272 p. ISBN-10: 0060559535, ISBN-13: 978-0060559533

Husain, Z. (2013). Effective communication brings successful organizational change. The Business \& Management Review, Vol. 3, No. 2, p. 8: http://www.abrmr.com/myfile/conference_proceedings/Con_Pro_12315/7-dubai13.pdf

IBM (2020). Company's info. Available Online: https://www.ibm.com/industries?lnk=min

International Federation of Robotics (2018). Robots and the Workplace of the Future. Positioning Paper, 36 p. Available online: https://ifr.org/downloads/papers/

International Labour Organization (2017). Basic Principles of Monitoring and Evaluation. 18 p. Available Online: https://www.ilo.org/wcmsp5/groups/public/---ed_emp/documents/publication/wcms_546505.pdf

Invest Lithuania (2018). Lietuvos privalumai ir inovacijos, Available online: https://investlithuania.com/lt/lietuvos-privalumai/inovacijos/

Iversen, E.; Dachs, B.; Poti, B.; Patel, P.; Cerulli, G.; Spallone, R.; Zahradnik, G.; Knell. M; Scherngell, T.; Lang, F. (2016). Internationalisation of business investments in $\mathrm{R} \& \mathrm{D}$ and analysis of their economic impact (BERD Flows). Luxembourg: European Commission. DOI: $10.02777 / 888034$

Jain, E.; Yadav, A. (2017). Marketing and Technology: Role of Technology in Modern Marketing. IOSR Journal of Business and Management, Vol. 19, No. 5, pp. 49-53 ISSN: 2278-487X

Jitterbit and Epicor (2019). Informa's Industry Week; Market survey. 17 p. Available Onine: https://cloud.kapostcontent.net/pub/8c501c1ef4fc-4030-844e-eac45cb3dc05/industryweek-slash-epicor-industry-4-dot-0-survey-report?kui=BW_X6phSwy-WRGUz3aAZZQ

Karlsson, C.; Rickardsson, J. Wincent, J. (2019). Diversity, innovation and entrepreneurship: where are we and where should we go in future studies? Small Business Economics (2019), 14 p. DOI: $\underline{10.1007 / \mathrm{s} 11187-019-00267-1}$

Kececi, E.F. (2018). Mechatronic Components. Butterworth-Heinemann, 248 p. ISBN-10: 0128141263, ISBN-13: 978-0128141267

Kikuchi, J.; Takeo, K.; Kosuge, K. (1998). Teleoperation system via computer network for dynamic environment. In proceedings of the IEEE International Conference of Robotics and Automation, Leuven, Belgium, pp. 3534-3539 DOI: 10.1109/ROBOT.1998.680988

Kikuchi, K.; Sakaguchi, K.; Sudo, T.; Bushida, N.; Chiba, Y.; Asai, Y. (2008). A study of wheel-based stair-climbing robot with a hopping mechanism. Mechanical Systems and Signal Processing, 22 (6), pp. 1316-1326, DOI: 10.1016/j.ymssp.2008.03.002

KPMG (2019). The Future of HR 2019: in the Know or in the No. Available online: https://home.kpmg/xx/en/home/insights/2018/11/thefuture-of-human-resources.html

Kurman, M.; Lipson, H. (2012). Fabricated: The New World of 3D Printing, Wiley Publishing, 320 p. ISBN-13: 978-1118350638, ISBN10: 1118350634

Laužikas, M.; Miliūtè A. (2017) The Role of Education on Entrepreneurship in Lithuania. In: Sauka A., Chepurenko A. (eds) Entrepreneurship in Transition Economies. Societies and Political Orders in Transition. Springer, Cham; ISBN: 978-3-319-57341-0 (Print) 978-3-319-57342-7 (Online)

Lee, Joon-Peel; Chang, Myung-Hee (2018). A Study on the Intention to Use Big Data Based on the Technology Organization Environment and Innovation Diffusion Theory in Shipping and Port Organization. Journal of Korea Port Economic Association, Vol.34, No.3, pp.159$182,1225-3855(\mathrm{pISSN})$

Marinescu R.; Lee, J.; Dechter, R.; Ihler, A. (2019) AND/OR search for marginal MAP, Journal of Artificial Intelligence Research, Vol. 63, No. 1, pp. 875-921, DOI: 10.1613/jair.1.11265 


\section{INSIGHTS INTO REGIONAL DEVELOPMENT}

ISSN 2669-0195 (online) http://jssidoi.org/jesi/

2021 Volume 3 Number 3 (September)

http://doi.org/10.9770/IRD.2021.3.3(5)

McClintock, M. (2019). Employee Monitoring to Optimize Business Processes. ProcessMaker, Available Online: https://www.processmaker.com/resources/customer-success/blog/employee-monitoring-to-optimize-business-processes/

McDonough, W. (2018). Video with co-author of The Upcycle: Beyond Sustainability--Designing for Abundance, speaks about efficiency vs. effectiveness, Available Online: https://youtu.be/B4QQZvqRtzA

McEwan, D.; Ruissen, G. R.; Eys, M. E.; Zumbo, B. D.; Beauchamp, M. R. (2017). The Effectiveness of Teamwork Training on Teamwork Behaviors and Team Performance: a Systematic Review and Meta-Analysis of Controlled Interventions. PLoS ONE. Vol. 12, No. 1: https://doi.org/10.1371/journal.pone.0169604

McHugh, R.; Zhang, H. (2018). Virtual Prototyping of Mechatronics for 21st Century Engineering and Technology. 12 p. Available Online: http://ilin.asee.org/Conference2010/Papers/A1_McHugh_Zhang.pdf

Mori, T. (1969). Mechatronics, Yasakawa Internal Trademark Application Memo, 21.131.01, July 12

Muñoz, R. M.; Sánchez de Pablo, J. D.; Peña, I.; Salinero, Y. (2016). The Effects of Technology Entrepreneurship on Customers and Society: A Case Study of a Spanish Pharmaceutical Distribution Company. Front. Psychol. Vol. 7; No. 978, 13 p. DOI:10.3389/fpsyg.2016.0097823

Nambisan, S.; Wright, M.; Feldman, M. (2019). The digital transformation of innovation and entrepreneurship: Progress, challenges and key themes. Research Policy, Vol. 48, No. 8, 10 p. DOI: 10.1016/j.respol.2019.03.018

Nilson. N. J. (1980). Principles of Artificial Intelligence. Morgan Kaufmann Publishers Inc., 476 p. ISBN:978-0-934613-10-1

Ong, S.K.; Yuan, M.L.; Nee A.Y.C. (2008) Augmented reality applications in manufacturing: a survey, International Journal of Production Research, Vol. 46, No. 10, pp. 2707-2742, DOI: $\underline{10.1080 / 00207540601064773}$

Onkelinx, J., Manolova, T. S.; Edelman, L. F. (2016). Human capital and SME internationalization: Empirical evidence from Belgium. International Small Business Journal, Vol. 34, No. 6, pp. 818-837 DOI: 10.1177/0266242615591856

Osman, I. (2002). The Handbook of Monitoring and Evaluation. International Federation of Red Cross and Red Crescent Societies. 163 p. Available Online: https://www.measureevaluation.org/resources/training/capacity-building-resources/basic-me-conceptsportuguese/IFRC_Monitoring\%20and\%20Evaluation\%20handbook.pdf

Pannaga, N.; Ganesh, N.; Gupta, R. (2013). Mechatronics - AnIntroduction to Mechatronics. International Journal of Engineering Research \& Technology (IJERT) Vol. 2, No. 8, 7 p. ISSN: 2278-018 https://www.ijert.org/research/mechatronics-an-introduction-to-mechatronicsIJERTV2IS80133.pdf

Pelser, T. (2014). The influence of Technology Strategies and their Link to Company Performance. Mediterranean Journal of Social Sciences, Vol. 5, No. 9, pp. 238-247, DOI: 10.5901/mjss.2014.v5n9p238. ISSN 2039-2117 (online) ISSN 2039-9340 (print)

Pirzada, K.; Ahmed, M. (2013). Effect of New Technology on Firms Business Objectives: A Case Study of Pak-Suzuki Company. International Journal of Business Administration, Vol. 4, No. 3, 7p. DOI: 10.5430/ijba.v4n3p95, ISSN 1923-4007(Print)

PricewaterhouseCoopers (2019). PwC's 22nd Annual Global CEO Survey, Technology trends 2019, 12 p. Available Online: https://www.pwccn.com/en/research-and-insights/ceo22/technology-trends-report-2019.pdf

PWC (2020). The power to perform: Human capital 2020 and beyond, 32 p. www.pwc.com/hc2020

Robinson. H.; MacDonald, B.; Broadbent, E. (2014). The Role of Healthcare Robots for Older People at Home. J Am Med Dir Assoc, Vol. 14, No. 9, pp. 661-7, DOI: 10.1016/j.jamda.2013.02.007. Epub 2013 Mar 30.

Rogers, E.M.; Shoemaker, F.F. (1971). Communication of Innovations. A Cross-Cultural Approach. 2d ed. New York: Free Press. 476 p. ASIN: B0006D070Y

Raven, F.H. (1994). Automatic control Engineering, 5 ${ }^{\text {th }}$ Edition, McGraw-Hill Series in Mechanical Engineering, 619 p. ISBN-10: 0070513414, ISBN-13: 978-0070513419

Saljoughi, M. J. H. (2017). Relationship between the Emotional Intelligence with the Job Burnout and Happiness of the High School Principals in Zahedan City. Iranian journal of educational Sociology, Vol. 1, No. 4, 9 p., Available Online: http://iase-idje.ir/article-1$\underline{305 \text { en.pdf }}$ 
INSIGHTS INTO REGIONAL DEVELOPMENT

ISSN 2669-0195 (online) http://jssidoi.org/jesi/

2021 Volume 3 Number 3 (September)

http://doi.org/10.9770/IRD.2021.3.3(5)

Satalkina, L.; Steiner, G. (2020). Digital Entrepreneurship and its Role in Innovation Systems: A Systematic Literature Review as a Basis for Future Research Avenues for Sustainable Transitions. Sustainability, Vol. 12, No. 2764 p. 27 DOI: 10.3390/su12072764

Soudahar, M. E. (2015). Mechatronics: A multidisciplinary field of engineering. International Journal of Advanced Research in Mechanical Engineering \& Technology (IJARMET), Vol. 1, No. 1. 29 p. ISSN: 2454-4736 (Online) ISSN: $2454-8723$ (Print) https://www.researchgate.net/publication/317562817_Mechatronics_A_Multidisciplinary_Field_of_Engineering

Shanga, S. M.; Wanga, Y. Y.; Wana, Q. Q.; Linb, F.; Zhoua, W. J. (2017). International Interventions to improve communication between nurses and physicians in the intensive care unit: an integrative literature review. Journal of Nursing Sciences; Vol. 5, No. 1, pp. 81-88: DOI: $10.1016 /$ j.ijnss.2017.09.007

Subramanian, B. (2020). The Rise in Artificial Intelligence Makes Emotional Intelligence More Important. A Data Science Foundation White Paper June, 11 p. Available Online: https://datascience.foundation/sciencewhitepaper/the-rise-in-artificial-intelligence$\underline{\text { makesemotional-intelligence-more-important }}$

Surbhi, S. (2018). Difference Between Efficiency and Effectiveness. Available Online: https://keydifferences.com/difference-betweenefficiency-and-effectiveness.html

Tencent (2019). Company's info. Available Online: https://www.tencent.com/en-us/about.html\#about-con-1

Treiblmaier, H.; Beck, R. (2019). Business Transformation through Blockchain. Palgrave Macmillan, 290 p. DOI: 10.1007/978-3-31998911-2, Hardcover ISBN: 978-3-319-98910-5

Udod, S.A.; Hammond-Collins, K.; Jenkins, M. (2020). Dynamics of Emotional Intelligence and Empowerment: The Perspectives of Middle Managers, SAGE Open April-June, pp. 1-9, DOI: 10.1177/2158244020919508

Vista Industrial Products, by Britney Blue (2013). Avantages and Disatvantages of Auromation in Manufacturing. Available Online: http://www.vista-industrial.com/index.php

Voehl, F. (1995). Deming The Way We Knew Him. Series: St Lucie, Publisher: CRC Press, 192 p. ISBN-10: 1884015549, ISBN-13: 9781884015540

Vancraen, F. (2019). Materialise Mission, Available Online: https://www.materialise.com/en/about-materialise/mission

Wilburn, K. M; Wilburn, H. R. (2018). The impact of technology on business and society. Global Journal of Business Research. Vol. 12, No. 1, pp. 23-39, ISSN: 1931-0277 (print), ISSN: 2157-0191 (online). www.theIBFR.com

Wilson, M. (2015). Implementation of Robot Systems. Elsevier Inc. 228 p. ISBN-978-0-124-04733-4.

WSPC (2020). Company's info. Available Online: http://wickmanspacecraft.com/ 
INSIGHTS INTO REGIONAL DEVELOPMENT

ISSN 2669-0195 (online) http://jssidoi.org/jesi/

2021 Volume 3 Number 3 (September)

http://doi.org/10.9770/IRD.2021.3.3(5)

\section{Appendix 1}

\section{Questionnaire}

Dear Madam/Sir, we are currently conducting research on the effectiveness and efficiency of applying mechatronics in business processes. Your answers would be of significant value to our investigation. We guarantee the confidentiality of your answers and the high standards of our research ethics. Thank you for taking part in our research.

What is your age?
A. $\quad 18-25$
B. $26-35$
C. $\quad 36-50$
D. 50 or more

Do you have a degree in robotics/mechatronics?

How many years of experience do you have in working in high-tech industries? (Indicate number of years)

If you needed a mechatronics specialist, would you employ a person with a degree in mechatronics? Why? (Explain your answer with at least two arguments)

From your point of view, what is the main goal of applying modern technologies in business processes? (Explain your answer with at least two arguments)

How would you evaluate the business strategy's orientation towards modern technology (including mechatronics)? Back your answer by two arguments.

Would you consider the opportunity and acknowledge the need to use mechatronics in strategy development/execution more frequently and on a bigger scope and scale? Why?

What high-tech solutions do you use to run your business processes? (Provide at least two examples) (If you do not use, please skip questions 7 and 8)

What obstacles do you face when applying mechatronics in business processes? (If your answer to the previous question was negative, please skip this question)

How often do you need to upgrade the high-tech tools implemented in your business processes?

In your opinion, how will mechatronics affect the future of your business? (Provide at least two examples)

Are you planning to implement mechatronics in your business processes?

In your opinion, what competitive advantages could companies gain after implementing mechatronics in their business processes?

What percentage of revenue a should high-technology company invest in main strategic departments to be successful and innovative? (choose the corresponding bracket)

\begin{tabular}{|l|l|l|l|l|l|}
\hline & $0-5 \%$ & $5-10 \%$ & $10-20 \%$ & $20-35 \%$ & More than 35\% \\
\hline Research and Development & & & & & \\
\hline Technology/Innovation & & & & & \\
\hline Marketing & & & & & \\
\hline HR & & & & & \\
\hline Other & & & & & \\
\hline
\end{tabular}

What percentage should a technologically less intensive company invest in main strategic departments to be successful? (choose the appropriate bracket)

\begin{tabular}{|l|l|l|l|l|l|}
\hline & $0-5 \%$ & $5-10 \%$ & $10-20 \%$ & $20-35 \%$ & More than 35\% \\
\hline Research and development & & & & & \\
\hline Technology/Innovation & & & & & \\
\hline Marketing & & & & & \\
\hline HR & & & & & \\
\hline Other & & & & & \\
\hline
\end{tabular}


INSIGHTS INTO REGIONAL DEVELOPMENT

ISSN 2669-0195 (online) http://jssidoi.org/jesi/ 2021 Volume 3 Number 3 (September) http://doi.org/10.9770/IRD.2021.3.3(5)

In your opinion, which of the following criteria are the most important to make a high-technology business effective and efficient (evaluate on the scale of 9 , where 9 refers to particularly important and 1 is an insignificant impact)?

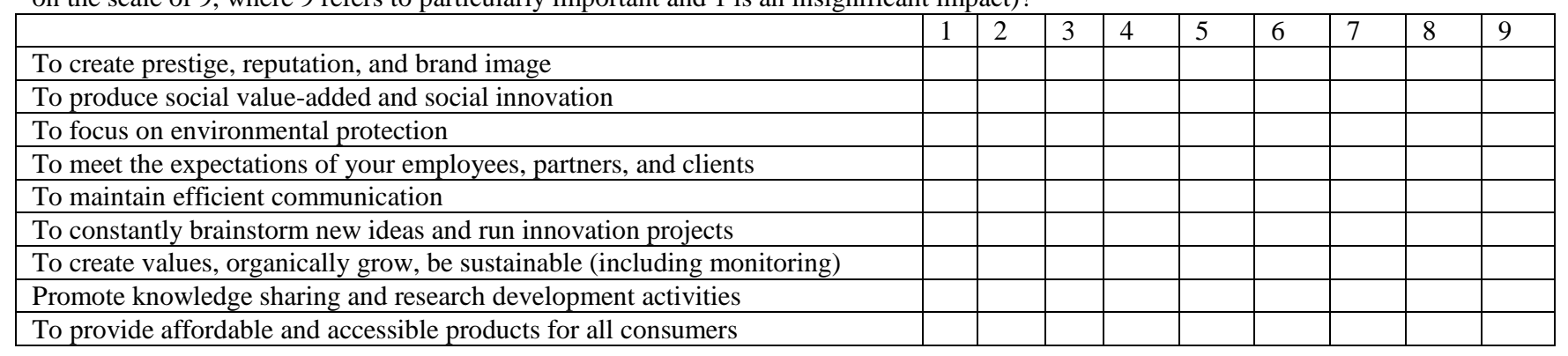

In your opinion, which of the following criteria are the most important to make a technologically less intensive company effective and efficient (evaluate on the scale of 9, where 9 refers to particularly important and 1 is not at all important)?

\begin{tabular}{|c|c|c|c|c|c|c|c|c|c|}
\hline & 1 & 2 & 3 & 4 & 5 & 6 & 7 & 8 & 9 \\
\hline \multicolumn{10}{|l|}{ To create prestige, reputation, and brand image } \\
\hline \multicolumn{10}{|l|}{ To produce social value-added and social innovation } \\
\hline \multicolumn{10}{|l|}{ To focus on environmental protection } \\
\hline \multicolumn{10}{|l|}{ To meet intentions of your employees, partners, and clients } \\
\hline \multicolumn{10}{|l|}{ To maintain efficient communication in the company } \\
\hline \multicolumn{10}{|c|}{ To constantly brainstorm new ideas and run innovation projects } \\
\hline \multicolumn{10}{|c|}{ To create values, organically grow and be sustainable (including monitoring) } \\
\hline \multicolumn{10}{|c|}{ Promote knowledge sharing and Research Development activities } \\
\hline To provide affordable and accessible products for all consumers & & & & & & & & & \\
\hline
\end{tabular}

Thank you for your time and assistance. We appreciate your collaboration. The research results will be available once the data is thoroughly and fully collected and interpreted.

Kind regards,

The research team of Vilnius University Business School

Viltè Morozovaite

Danielius Karpičius

Mindaugas Laužikas

Aistè Miliūtè 
INSIGHTS INTO REGIONAL DEVELOPMENT

ISSN 2669-0195 (online) http://jssidoi.org/jesi/ 2021 Volume 3 Number 3 (September) http://doi.org/10.9770/IRD.2021.3.3(5)

Appendix 2

Expert Codes

High-tech focus group

\begin{tabular}{|l|l|l|l|l|}
\hline Codes & IT COMPANY H1 & IT COMPANY H2 & IT COMPANY H3 & IT COMPANY H4 \\
\hline What is your age? & $\begin{array}{l}26-35 \\
\text { b }\end{array}$ & $\begin{array}{l}26-35 \\
\text { b }\end{array}$ & $\begin{array}{l}\text { b-36-50 } \\
\text { b }\end{array}$ \\
\hline $\begin{array}{l}\text { Do you have a degree in } \\
\text { robotics/mechatronics? }\end{array}$ & $\begin{array}{l}\text { No } \\
\text { A }\end{array}$ & Ao & Combined with IT & No \\
\hline $\begin{array}{l}\text { How many years have you been } \\
\text { working in high-tech industries? }\end{array}$ & 7 & y & B & A \\
\hline
\end{tabular}

Focus group of experts from the technologically less intensive industry

\begin{tabular}{|c|c|c|c|c|}
\hline Codes & $\begin{array}{l}\text { TEXTILE } \\
\text { COMPANY T1 }\end{array}$ & $\begin{array}{l}\text { TEXTILE } \\
\text { COMPANY T2 }\end{array}$ & $\begin{array}{l}\text { TEXTILE } \\
\text { COMPANY T3 }\end{array}$ & $\begin{array}{l}\text { TEXTILE } \\
\text { COMPANY T4 }\end{array}$ \\
\hline What is your age? & $\begin{array}{l}18-25 \\
\mathrm{a}\end{array}$ & $\begin{array}{ll}50+ \\
\mathrm{d}\end{array}$ & $\begin{array}{l}6-50 \\
\mathrm{c}\end{array}$ & $\begin{array}{l}6-50 \\
\mathrm{c}\end{array}$ \\
\hline $\begin{array}{l}\text { Do you have a degree in } \\
\text { robotics/mechatronics? }\end{array}$ & $\begin{array}{l}\text { No } \\
\text { A }\end{array}$ & $\begin{array}{l}\text { No } \\
\text { A }\end{array}$ & $\begin{array}{l}\text { No } \\
\text { A }\end{array}$ & $\begin{array}{l}\text { No } \\
\text { A }\end{array}$ \\
\hline $\begin{array}{l}\text { How many years have you worked } \\
\text { in high-tech industries? }\end{array}$ & $\begin{array}{l}0 \\
\mathrm{x}\end{array}$ & $\begin{array}{l}0 \\
\mathrm{x}\end{array}$ & $\begin{array}{l}13 \\
\mathrm{y}\end{array}$ & $\begin{array}{l}2 \\
\mathrm{x}\end{array}$ \\
\hline
\end{tabular}

Dr. Mindaugas LAUŽIKAS is a Professor at Vilnius University Business School, Adjunct Professor at American University of Malta, Doctor of Economic Sciences, Director of GILE Experts (Malta). Lecturing experience in countries, such as Georgia, Sweden, France, Spain, Italy, Malta, Moldova, South Korea and Lithuania, is supported by publications in the field of knowledge economy, entrepreneurship and innovation. Research interests: national systems of innovation, entrepreneurship, knowledge and innovation management, innovation and human resource strategies, business intelligence.

ORCID ID: http://orcid.org/0000-0002-6113-7794

Aistė MILIŪTÉ is a teacher/researcher at Vilnius University Business School and entrepreneur within the mineral water and healthcare industries, a founder of AKVAVITA company.

ORCID ID: $\underline{\text { http://orcid.org/0000-0002-9667-3730 }}$

Viltė MOROZOVAITÉ is a Researcher at Vilnius University Business School.

ORCID ID: https://orcid.org/0000-0002-8509-9710

Danielius KARPIČIUS is a Researcher at Vilnius University Business School.

ORCID ID: https://orcid.org/0000-0002-4370-5348

Make your research more visible, join the Twitter account of INSIGHTS INTO REGIONAL DEVELOPMENT:

@IntoInsights

Copyright (C) 2021 by author(s) and VsI Entrepreneurship and Sustainability Center

This work is licensed under the Creative Commons Attribution International License (CC BY).

http://creativecommons.org/licenses/by/4.0/

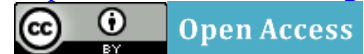

